\title{
シンポジウムロCampylobacter 食中毒の制御
}

-Control of Campylobacter Food Poisoning

\section{司会の言葉}

Introduction

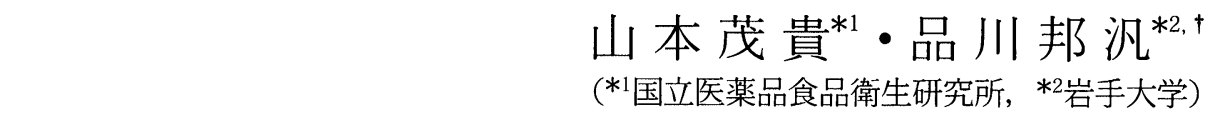

Shigeki Yamamoto*1 and Kunihiro SHINAGawa*2

${ }^{*}{ }^{*}$ National Institute of Health Sciences, 1-18-1 Kamiyoga, Setagaya-ku, Tokyo 158-8501)

(*2Iwate University, 3-18-8 Ueda, Morioka, Iwate 020-8550)

\section{1.はじめに}

近年，世界各国で Campylobacter 食中毒加増加し，そ の制御が重要となってきている。Campylobacter 食中毒 の起因菌は主に Campylobacter $($ C. $)$ jejuni と C. coli で ある.わが国においては C. jejuniによるあのが大多数 を占めており，その制御が重要な課題となってきてい る.

今回のシンポジゥムでは, Campylobacter 食中毒の制 御について 4 つのテーマから議論を深めたいと考え, ま ず, Campylobacter 食中毒の発生状況, 次いで Campylobacter の酸素ストレスに対する応答性について菌の coccoid 化を中心に議論する。 また，家畜衛生分野にお ける Campylobacter 而性菌の現状を生産段階に打ける 而性菌発生状況を紹介し, 最後にCampylobacter 食中毒 の発生とその制御についてまとめていくことにした。

\section{Campylobacter 食中毒の発生状況}

わが国の食中毒統計によると 1996 年以降事件数は急 增しており, 事件数の増加に対し患者数は 1,500〜 2,500 人前後の増加をしている. しかし，全体では急激 な増加なく推移している。これは一部の自治体から「1 事件当たり患者 1 人」の事例が届け出されていること, また，全国的に 1 事件当たりの患者数が減少しているこ とに起因していることによると推測される．そのため, 1 人事例と 2 人以上事例を分けて統計されることとなっ た。

Campylobacter 食中毒の患者発生のピークは 5, 6 月 頃とサルモネラや腸炎ビブリオに比べて 1,2 力月早い. また，冬期にも発生していることが特徴である.

\footnotetext{
$\dagger$ 連絡先

*1 画158-8501 東京都世田谷区上用賀 1-18-1

*2 可020-8550 盛岡市上田 3-18-8
}

\section{Campylobacter の血清型別と疫学}

Campylobacter jejuni の血清型別法は，易熱性抗原に よるLior らの型別と，耐熱性抗原による Penner らの 型別方法が国際的に使用されている。わが国では Campylobacter の血清型別として, Penner の型別用血 清が市販されているが，Lior 型別用血清は，全国衛生微 生物協議会のカンピロバクター・レファレンスセンター グループ (秋田県, 東京都, 愛知県, 大阪府, 広島市, 山口県, 熊本県の各地方衛生研究所) でそれぞれ作製さ れ，分離菌株の型別が実施されている．Lior 型別では Lior 4, 7 などによるCampylobacter 腸炎が多く発生し ている，一方，Campylobacter腸炎後にギランバレ一症 候群を発症する菌株としては，血清型の Penner HS19 型が関与していることが示唆されている.

\section{4. 酸素ストレスへの応答性}

Campylobacter は微好気性菌であり，好気条件下では 酸素によるストレスを受ける，そのため，本菌は好気条 件下では増殖することができず，一般に食品中では増殖 を示さず，生残性も低いと考えられている。そそ机むか かわらず，食中毒事件が世界各国で増加していることか ら, 本菌は好気条件下で増殖はできないまでも何らかの 方法で生残し，これをヒトが撕取した場合，ヒトの腸管 で増殖, 発症させると推察される。酸素ストレス下での 生残様式として coccoid 化が考えられており，そのメ力 ニズムの解明は, Campylobacter 食中毒の制御に大いに 貢献すると期待される.

\section{5. 家畜衛生分野における Campylobacter の耐性菌 の現状}

Campylobacter は鶏や豚および牛に感染するが，宿主 動物にはほとんど病気を起こさず，腸管内に長期間生存 する．家畜衛生分野ではさまざまな抗生物質が使用され ているが, それらの抗生物質に対し薬剤耐性菌が出現 
108 日食微誌 Vol. 23 No. 32006

し，ヒトの医療に重大な影響を与えることが国際的に議 論されている. 特に, キノロン系抗生物質に耐性を示す 多剂耐性菌が報告されてきている，家畜における抗生物 質の使用規制の方向にあるが，食用動物においては生産 量の確保と，抗生物質の使用問題に関して議論を深めて いく必要がある.

\section{Campylobacter 食中毒の発生とその制御}

Campylobacter は家禽, 特に鷄において問題であり, 䳕肉に由来するCampylobacter 食中毒が多数発生して いる，安全で衛生的な食鳥肉を生産するためには，食鳥 肉によるヒトの危害発生 (食中毒) について, 発生頻度, 原因物質, 発生要因などを十分に把握して，その対策を 構筑することが必要である.
一般的に, 食肉の危害物質としては微生物学的（食中 毒起因菌などの病原微生物), 化学的 (残留抗生・抗菌物 質, 農薬など）および物理学的要因（食鳥肉中の骨など 異物）があるが, 最む発生頻度の高いものは微生物学的 要因 (カンピロバクター, サルモネラ, などの食中毒菌) によるあのである.ささらに，これらの微生物污染防止と しては, 食鳥（ブロイラー）生産から食鳥処理場でのと 殺・解体, 加工, 流通・販売, さらに消費に至るすべて の段階まで一貫した衛生管理システムを確立することが 必要である。

そのためには「農場から食卓」までの各段階において, HACCP 方式導入の前段階としての GAP または GMP を確立し, さらに HACCP 方式を構築する。 また, SOP およびSSOP などを作成することも必要である. 


\section{シンポジウム Campylobacter 食中毒の制御}

- Control of Campylobacter Food Poisoning

\section{カンピロバクター食中毒の発生状況}

Occurrence of Campylobacter Food Poisoning

横山敬子 ${ }^{\dagger}$

（東京都健康安全研究センター）

Keiko Yokoyama

(Tokyo Metropolitan Research Laboratory of Public Health)

\section{1. はじめに}

1977 年, イギリスの Skirrow が下痢症患者糞便から Campylobacter jejuni subsp. jejuni (以下 C. jejuni) を 分離し, 本菌がヒトの下痢症起因菌として認められてか ら約 30 年を経た今日, 多くの先進諸国においてカンピ ロバクターは高頻度に検出される下痢症起因菌となっ た. わが国であ, 近年カンピロバクター食中毒の急増が 目立っている. 本稿では, 変貌する食品媒介感染症の中 で, 現在注目されているカンピロバクター食中毒の発生 状況について紹介する.

\section{2. カンピロバクター集団食中毒の発生状況}

カンピロバクター食中毒が全国食中毒統計 ${ }^{1)}$ に掲載さ れた 1983 年から 2004 年までの患者数 2 人以上の事件 および患者数を図 1 に示した. 1983 年から 1996 年ま での事例数を見ると, 年間数十件程度で推移していた が，1996 年に多発した腸管出血性大腸菌 O157 集団事 例を契機に人々の食中毒に対する関心の高まり，一部の 地方自治体の届出方法の変更で患者 1 人の散発事例が 集計され始めたことも影響し，本食中毒事例数は急激な 増加を示し, 2004 年は 558 事例に至った。なお， 1998 年からは患者数 1 人事例と 2 人以上の事例を分けて報 告がなされるようになったが， 2 人以上の事例を比べて あ，本菌食中毒事例は著しい増加傾向にある.

患者数を見ると， 1980 年代では，1,378～9,497 人と 年により大きな増減があった．これは，後述する学校給 食を原因とする発生により，1 事件あたりの患者数が多 いことが理由と考えられる. 近年は 1 事例あたりの患者 数が少ないため大きな変動むなく，患者総数は 2,000 人 前後で推移している.

原因施設別に見ると，1983～1992 年には，学校（主 に学校給食）で発生した事例が多かったが，学校給食に

\section{連絡先}

巴169-0073 東京都新宿区百人町 3-24-1
おける衛生対策強化の効果により学校での発生は激減し た. それに引き換え，飲食店での発生が急増している (図 2). また, 統計上の数值としてあがっているのは, その一部に過ぎない，家庭での事例は潜在的に数多くあ ると推察される。

月別発生状況を図 3 に示した. 本食中毒は, 冬季を含 め年間を通じて発生しているが, 夏季に発生件数のピー クを示すサルモネラ食中毒と比較するとそのピークにず れがあり, 初夏 5〜 6月に発生件数が増加しており, 気 温の最む高い 7〜9月には減少傾向を示す.

\section{3. 感 染 源}

1999 2003 年に都内で発生したカンピロバクター食 中毒 81 事例 2 の の原因食品（推定を含む）を図 4 に示し た. 原因が判明（推定も含む）したものの内訳を見ると, 鶏肉関連食品が最も多く $63.0 \%$ 占めた。次いで牛レ バーが $3.7 \%$ ，鶏および牛レバー $2.5 \%$ の順であった．以 前からカンピロバクター食中毒の原因食品として鶏肉の 関与が示唆されており, その傾向は現在も変わりない. 鶏肉関連食品の調理形態を見ると, その $66.7 \%$ が生ある いは生に近い加熱不十分で契食されていた，鶏肉を生で 食べることは, 一部の地域では昔からの食習慣として あった. しかし，最近のグルメブームにより鶏刺しなど の生肉を提供する飲食店が全国的に広がりかつ増加した ことも，全国的なカンピロバクタ一食中毒の急増の一因 となっているように推察される. 焼肉店などで牛のレ バー刺を喫食したために食中毒にかかる場合む多い。こ のようにカンピロバクター食中毒の増加の原因を調べる と, 生肉を食べるという食文化の変化が問題点として浮 かび上がってきた.

原因食品が特定されなかった事例は $27.2 \%$ にんだ が, その理由として, カンピロバクター食中毒では, 少 量菌による感染の成立 ( $>10^{2}$ 個), 長い潜伏時間 $(1 \sim 7$ 日）に加えて, 通常の大気条件化で, 本菌は急速に死滅 する生理学的特徴に起因することが考えられる.

カンピロバクター食中毒の発生要因を見ると, 生食, 


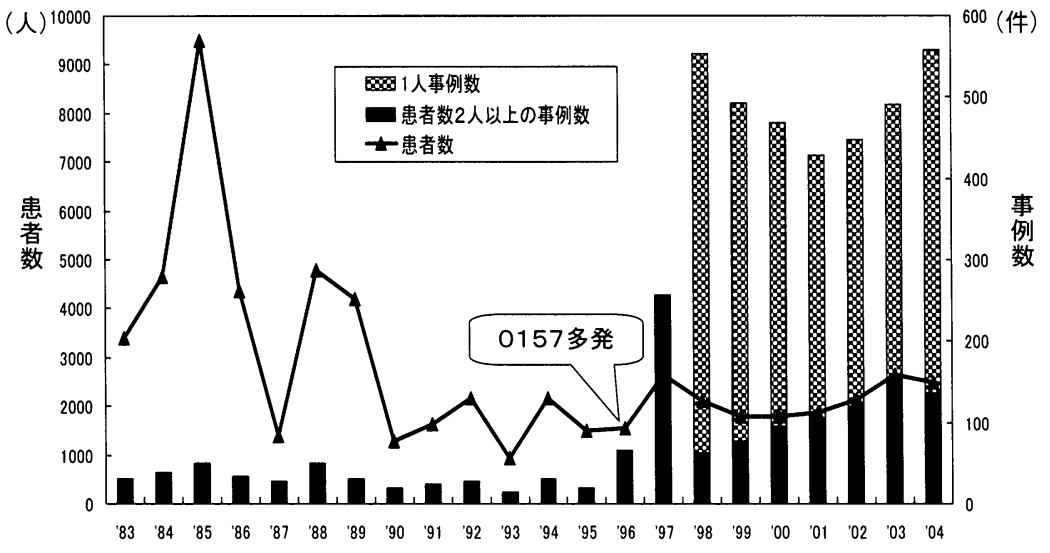

図1. カンピロバクター食中毒の発生状況 （全国・1983 2004 年).

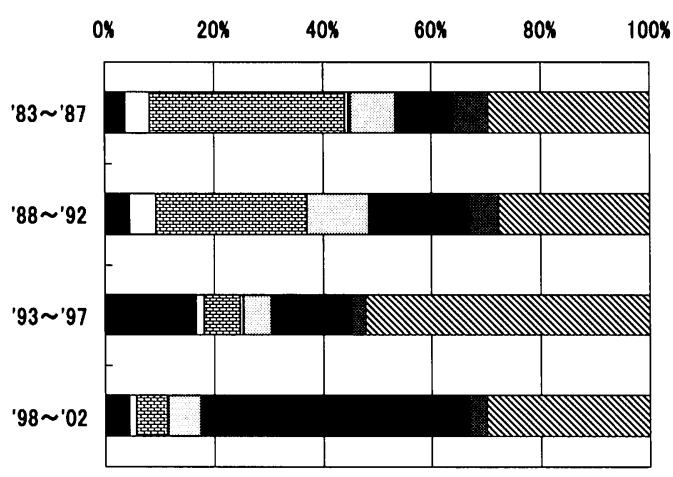

図2. カンピロバクター食中毒事例の原因施設 （全国・1983 2002 年).

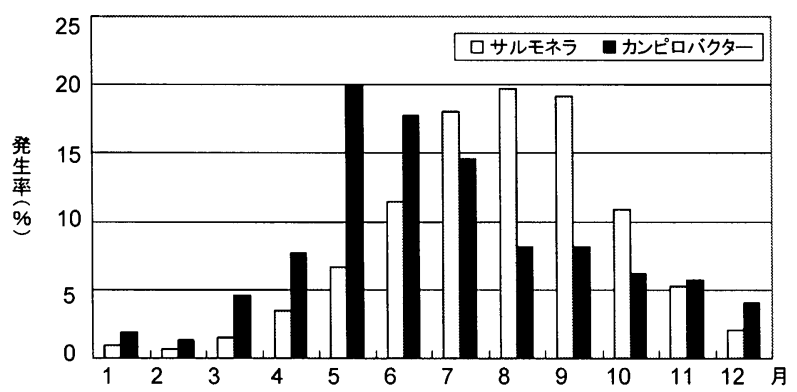

図 3. カンピロバクターとサルモネラ食中毒の月別発生率 (全国・1983 2003 年).

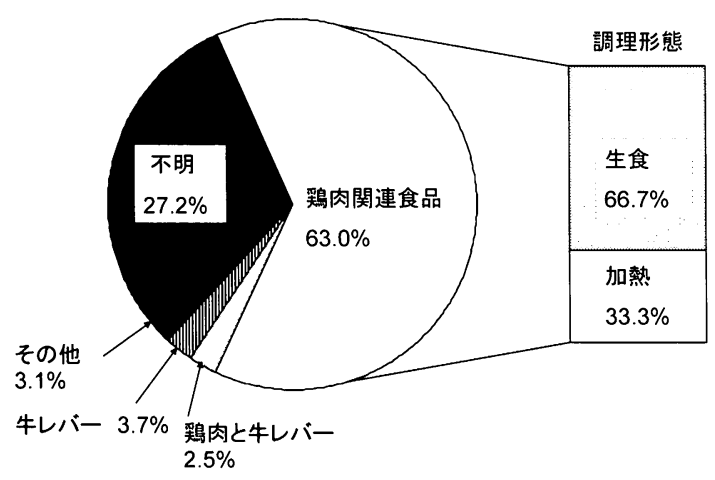

図 4. カンピロバクター食中毒の原因食品（東京都 81 事 例・1999 2003 年).
加熱不足と並び二次污染が挙げられ, 「調理器具の使い 分けがない」「洗浄不十分」「相互污染」などによるもの が多い3). 一例を挙げると, 学校給食での事例が減少し ている一方で, 学校の調理実習による食中毒が増加傾向 にある，都内で発生した調理実習によるカンピロバク タ一食中毒事例を表 1 に示した. 献立は, いずれにも䳕 肉が使用されており「とりわさ」「鶏の霜降り」「親子井」 「チキンピラフ」などである。「親子村」や「チキンピラ フ」は十分加熱調理がなされていたことから, 調理中の 二次污染が原因と推察された。

一方, スエーデンでの調査 ${ }^{4)} に よ る と ， 6$ 歳未満の小 児では本菌下痢症の感染源として, 鶏肉よりも飲料水 (井戸, 湖, 川), ペット, バーベキュー, 牛乳 (未殺菌) が上位を占めていると報告されている，わが国でも簡易 水道の滅菌不備, 配管の破損などを発生要因とする水系 感染事例（表 2）もあり, 頻度は少ないむのの一度事件 が発生すると大規模事例につながることも多いので注意 を要する，また，欧米では生牛乳を原因とする事例が多 いが，わが国では加熱殺菌乳が流通しており，そのよう な発生例は見られていない. このように，カンピロバク ター食中毒の感染源には年秢, 生活環境, 食生活などの 違いにより特徵が見られるが，わが国においては，本菌 食中毒の感染源として鶏肉が最も重要である.

\section{4. カンピロバクター散発患者の発生状況}

C. jejuni は主要な集団食中毒起因菌であると同時に, 散発下痢症患者から分離される下痢症起因菌の上位に位 置している，しかし，わが国では，散発患者を含めた発 生状況の把握には至っていないのが実態である. そこ で, カンピロバクター腸炎散発患者の発生状況として図 5 に 2003 年に駒込病院で検出された細菌性下痢症にか かわる腸管系病原菌の検出状況を示した ${ }^{5)}$. 最も多く検 出された病原菌は, Campylobacter であり，34.8\%の検 出率であった。

都立病院（駒込・墨東）において散発患者から分離さ れた Campylobacter の菌種の内訳を見ると，分離された 
表 1. 都内で発生した調理実習によるカンピロバクター食中毒

\begin{tabular}{|c|c|c|c|c|c|}
\hline 発生年 & 月 & 学校種別 & 実習参加者 & 患者数 & 献立 \\
\hline 1984 & 6 & 短期大学 & 45 & 8 & とりわさ, 天ぷら, 揚げ物, 水羊美, かき玉汁など \\
\hline 1997 & 6 & 高等学校 & 43 & 5 & 親子井, ほうれん草扒ひたし，味噌汁 \\
\hline 2001 & 6 & 短期大学 & 46 & 5 & 親子斗，アスパラガス梅奨油和え，水羊羍 \\
\hline 2002 & 6 & 高等学校 & 26 & 11 & 鶏肉解剖実習 $\rightarrow$ 唐揚げ, 棒々鶏, 肉団子スープ \\
\hline 2002 & $4 \sim 5$ & 高等学校 & 293 & 38 & 親子井, ほうれん草胡麻和え，吸い物 \\
\hline 2003 & 5 & 高等学校 & 146 & 69 & 親子井, カレーチキンピラフ, 野菜サラダ, スープなよ゙ \\
\hline 2003 & 5 & 大学 & 40 & 27 & 鶏の霜降り, カッオ土佐造り, 五目蒸しなよ゙ \\
\hline 2003 & 11 & 中学校 & 9 & 8 & 生物実習 $\rightarrow$ 鶏肉をホットプレートで塩焼き \\
\hline
\end{tabular}

表 2. カンピロバクターによる水系感染事例（全国・1982２002 年・患者100 名以上）

\begin{tabular}{|c|c|c|c|c|c|c|}
\hline 年 & 月 & 場所 & 喫食者 & 患者 & 原因 & 発生要因 \\
\hline 1982 & 10 & 札幌 & 不明 & 7,751 & 飲料水㧍よび使用した食品 & 飲料水の污染, E. coli $\mathrm{O} 6$ との混合感染 \\
\hline 1983 & 4 & 新潟 & 226 & 116 & 上水道 & 配管工事または漏水箇所からの污染 \\
\hline 1985 & 9 & 熊本 & 318 & 214 & 小学校給食施設 & 学校自家水道の破損による污染 \\
\hline 1985 & 6 & 大分 & 8,151 & 525 & レストランの使用水 & 使用水の污染 \\
\hline 1986 & 8 & 長野 & 441 & 318 & キャンプ場の飲料水 & 滅菌装置の不備 ～～～～～～～ \\
\hline 1987 & 5 & 新潟 & 1,106 & 398 & 神社水飲場の涌き水 & 飲料水の污染, 未消毒水 \\
\hline 1988 & 5 & 東京 & 不明 & 677 & 井戸水 & 水源污染, 水質管理の不徹底 \\
\hline 1988 & 5 & 東京 & 不明 & 120 & 井戸水 & 水源污染, 水質管理の不徹底 \\
\hline 1988 & 5 & 熊本 & 1,054 & 234 & 高校の飲用井戸水 & 滅菌装置の不備 \\
\hline 1989 & 7 & 新潟 & 184 & 169 & 飲料水 & 滅菌器の故障 \\
\hline 1989 & 7 & 長野 & 1,311 & 194 & 簡易水道 & 簡易水道の污染 \\
\hline 1990 & 7 & 広島 & 259 & 109 & 団地専用水道 & 消毒設備がない \\
\hline 1991 & 5 & 新潟 & 167 & 105 & 観音堂の湧き水 & 湧き水の污染 \\
\hline 1994 & 3 & 静岡 & 184 & 122 & 旅館の使用水 & 貯水槽の管理不良, E. coli O169 と混合 \\
\hline
\end{tabular}

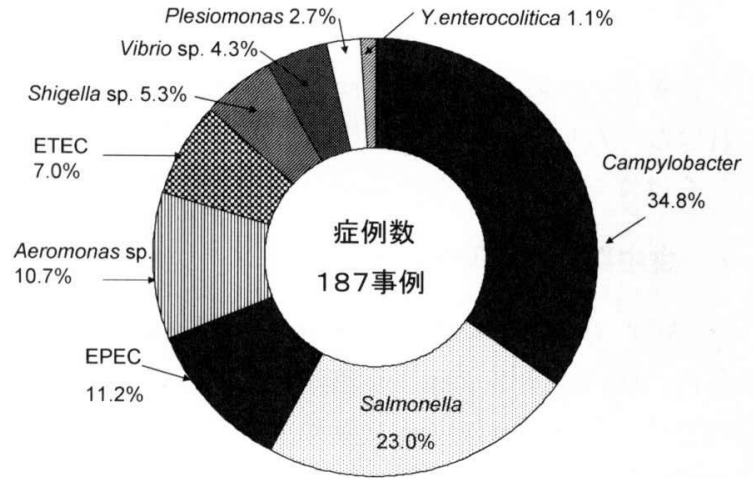

図 5. 細菌性下痢症における腸管系病原菌の検出状況 (都立駒込病院・2003 年).

カンピロバクターの $94.3 \%$ が C. jejuni, 次いで C. coli 4\%,C. fetus 1.3\%であった（表 3). この数值から見て 屯, カンピロバクター下痢症は, C. jejuni 下痢症といっ ても過言ではなかろう。 また, 散発 C. jejuni 腸炎患者 1,000 人の性別を見ると，男性 $62.2 \%$ ，女性 $37.8 \%$ で男 性の罹患率が高かった。年齢構成を見ると, 20 代が $43.2 \%$ を占め, ピークが認められた。次いで 10 代が $16.6 \%, 30$ 代が 14.1\%, 0 9 歳が 13.4\%で比較的年齢 の若い患者が多かった（図6）.

また，カンピロバクター腸炎は海外旅行者などから分 離される輸入感染症としても頻度の高い病原菌であるこ とが示されている.

\section{5. 分離菌株の血清型}

食中毒事例が発生した際, その原因究明のために菌型 試験および血清型別試験を実施している。 カンピロバク ターの血清型別は, 他の食中毒菌に比べ普及しておら ず，血清型別を実施していない検査施設屯多い，特に市 販血清のない Lior 型別については, 全国衛生微生物協 議会のカンピロバクター・レファレンスグループ（秋田 県, 東京都, 愛知県, 大阪府, 広島市, 山口県, 熊本県 の各地方衛生研究所）で型別用血清を作成し分離菌株の 型別を実施している6).

東京都での血清型別成績を図 7 に示した. 1997〜 2004 年に発生したカンピロバクター集団食中毒 100 事 例 (東京都) で患者粪便から分離されたC. jejuniについ て血清型別を行った成績では，60\%の事例で複数の血清 型の菌が分離されているが，集団食中毒由来株では, LIO7 が最む多い血清型であり, 次いでLIO4, TCK26 が続いていた.

\section{6. 鶏肉の污染状況}

カンピロバクターは, 家畜や家禽の腸管内に広く分布 し, と場, 食肉処理場における処理工程での交差污染に より食肉が污染される. 特に鶏肉での污染率は高い. 2002 2003 年に当センターで実施した市販鶏肉におけ る部位別カンピロバクター污染状況調査では, 正肉 (114 件) から C. jejuni は 67 件 (59\%), C. coli は 9 件 
表 3. 散発患者から分離された菌種別カンピロバクター分離株数

\begin{tabular}{|c|c|c|c|c|c|c|}
\hline \multirow{2}{*}{ 菌種 } & \multicolumn{5}{|c|}{ 分離年 } & \multirow{2}{*}{ 計 $(\%)$} \\
\hline & 2000 & 2001 & 2002 & 2003 & 2004 & \\
\hline C. jejuni & 175 & 173 & 203 & 209 & 198 & $958(94.3)$ \\
\hline C. coli & 13 & 2 & 7 & 10 & 9 & $41(4.0)$ \\
\hline C. fetus & 2 & 4 & 0 & 3 & 4 & 13( \\
\hline C. lari & 1 & 1 & 0 & 0 & 0 & $0.2)$ \\
\hline Campylobacter spp. & 0 & 0 & 0 & 0 & 1 & $0.1)$ \\
\hline Helicobacter spp. & 0 & 0 & 0 & 0 & 1 & $1(0.1)$ \\
\hline 計 & 191 & 180 & 210 & 222 & 213 & $1,016(100)$ \\
\hline
\end{tabular}

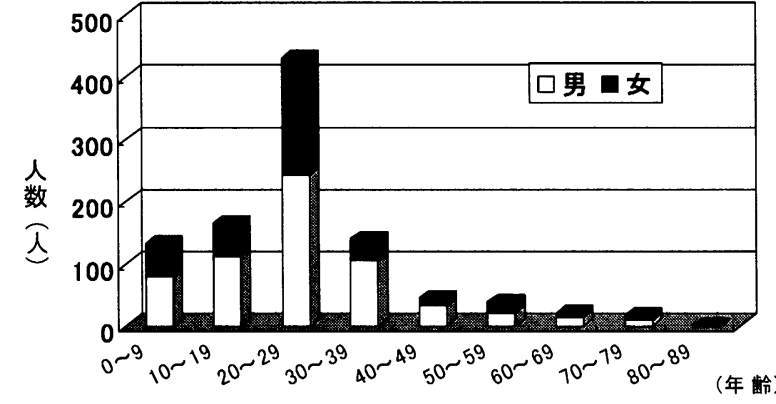

図6. カンピロバクター患者の年齢構成（都立病院・ $2000 \sim 2004$ 年).

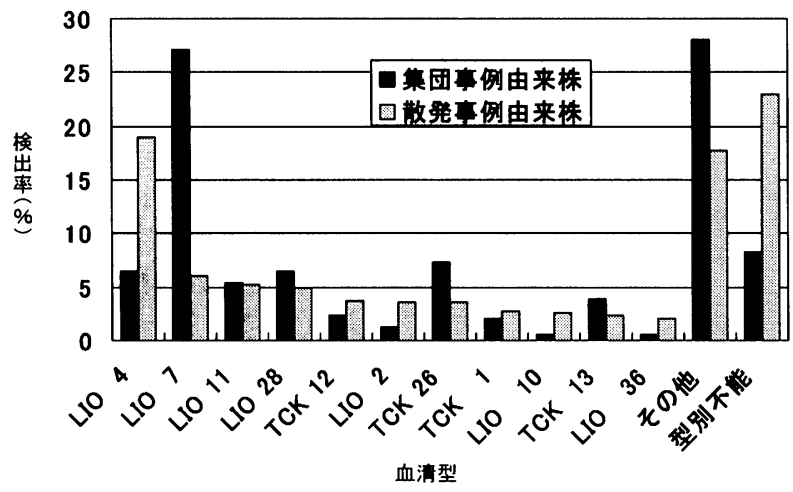

図 7. 集団および散発カンピロバクター腸炎患者由来 $C$. jejuni の血清型（東京・1997 2004 年).

(8\%), 内臓肉（210 件）では C. jejuni 148 件 (70\%), C. coli 23 件 (11\%) 検出されている（表 4). 一方, 同調査 時における輸入冷凍肉の検査ではカンピロバクターは検 出されていない，その理由として，凍結や長時間の輸送 によりカンピロバクターが死滅，あるいはVNC 状態に なり検出されなかったと推察される. 鶏肉のカンピロバ ク夕一検査法として公定法は定められていない，検査方 法による違いが，分離率に大きく影響し問題になってい ることから, 現在, 食品からのカンピロバクター標準検 査法について国立医薬品食品衛生研究所を中心として検 討中である.

このように市販流通䳕肉が本菌に高率に污染されてい る状況下で, 生あるいは生に近い状態で鶏肉を喫食する 行為が, カンピロバクター食中毒に直結することを再認 識することが必要であろう。しかし, 現在生食用食肉の 衛生基準として, 生食用食肉（牛または馬の肝臓または
表 4. 市販鷄肉における部位別カンピロバクター污染状況 （2002２003 年実施）

\begin{tabular}{llrrr}
\hline & \multirow{2}{*}{ 部位 } & 検査件数 & \multicolumn{2}{c}{ 陽性件数 (\%) } \\
\cline { 4 - 5 } & & & C. jejuni & C. coli \\
\hline 正肉 & むむ肉 & 31 & $23(74)$ & $5(16)$ \\
& むね肉 & 48 & $29(60)$ & $1(2)$ \\
& 手羽先 & 4 & $2(50)$ & $1(25)$ \\
& ササミ & 27 & $13(7)$ & $2(7)$ \\
& 輸入肉 & 4 & $0(0)$ & $0(0)$ \\
\hline 小計 & & 114 & $67(59)$ & $9(8)$ \\
\hline 内臟肉 & 肝 & 48 & $40(83)$ & $10(21)$ \\
& 砂肝 & 48 & $41(85)$ & $4(8)$ \\
\hline 小計 & & 96 & $81(84)$ & $14(15)$ \\
\hline 合計 & & 210 & $148(70)$ & $23(11)$ \\
\hline
\end{tabular}

肉）は糞便系大腸菌群およびサルモネラ属菌が陰性でな ければならないという成分規格目標があるのみで，鶏肉 あしくはカンピロバクターにかかわる基準はない.

\section{7. 食中毒予防対策への取り組み}

全国的なカンピロバクター食中毒の増加に対して, 国 や各自治体はさまざまな取り組みを行っている，厚生労 働省では「牛レバーによるカンピロバクタ一食中毒予防 について (Q\&A)」(http: / / www. mhlw.go.jp / qa / syokuhin/campylo/index.html) 作成し注意喚起し ている. 東京都では, 東京都食品安全条例に基づき設置 されている東京都食品安全情報評価委員会が「カンピロ バクター食中毒の発生を低減させるために」(http:// www.fukushihoken.metro.tokyo.jp/anzen/hyouka/ campylo/index.html) というテーマを採り上げ予防対 策を講じるための検討を行った。東京都は, 消費地とい う立場から, 都民自らが積極的にカンピロバクター食中 毒を予防できるように消費段階での対策の提言を行い, 各種の媒体を通じて具体的な情報提供を行っている. し かし, 現在もなおカンピロバクター食中毒は多発してい る.やはり, 根本的な対策である食用鶏肉の衛生管理が 徹底され，カンピロバクター・フリーの鶏肉が供給され ることが理想である. そして，さらなる食中毒予防のた めの知識の啓蒙, 教育の必要性を説いていくことが重要 である. 


\section{文献}

1）厚生労働省医薬食品局食品安全部監視安全課編：食中毒 統計（1983～2004 年版), 厚生労働省医薬食品局食品安 全部監視安全課発行.

2）東京都福祉保健局健康安全室編：東京都の食中毒（1999 ２003 年版)，東京都福祉保健局健康安全室食品監視課 発行.

3）厚生労働省医薬食品局食品安全部監視安全課編：全国食 中毒事件録（1995１997 年版）, 厚生労働省医薬食品局 食品安全部監視安全課発行.
4) Carrique-Mas, J., Andersson, Y., Hjertqvist, M., Svensson, A., Torner, A. and Giesecke, J .: Risk factors for domestic sporadic campylobacteriosis among young children in Sweden. Scand. J. Infect. Dis., 37(2), 101-110 (2005).

5) 根岸久実子, 水野裕之, 小川康子, 本間 操, 中島重彦, 鈴木智一, 設楽美典, 佐々木吉夫, 大林民典：最近 6 年間 の駒込病院における下痢起因菌の検出状況. 東京都保健 医療学会誌, 108, 40-41 (2005).

6）国立感染症研究所厚生労働省健康局結核感染症課編：病 原微生物検出情報, 27, 173-175 (2006). 


\title{
シンポジウムロCampylobacter 食中毒の制御
}

- Control of Campylobacter Food Poisoning

\section{カンピロバクターの酸素ストレスに対する応答性}

Aerobic Stress Responses of Campylobacter jejuni/coli

\author{
山崎学*1,*2, ・五十君靜信 ${ }^{* 1}$-山本茂 貴*1 \\ (*1国立医薬品食品衛生研究所, *2現 微生物化学研究会) \\ Manabu YAMASAKI ${ }^{* 1, * 2}$, Shizunobu IgImI ${ }^{* 1}$ and Shigeki YAmamoto*1 \\ $\left({ }^{* 1}\right.$ National Institute of Health Sciences, Kamiyoga, Setagaya-ku, Tokyo 158-8501, ${ }^{\dagger}$ Corresponding author) \\ $\left({ }^{* 2}\right.$ Microbial Chemistry Research Foundation, Kamiosaki, Shinagawa-ku, Tokyo 141-0021)
}

\section{1.はじめに}

食中毒起因菌である Campylobacter jejuni/coli (以 下,カンピロバクター) は増殖に酸素を要求するものの, 大気条件下では生育できない微好気性細菌である。発育 は酸素濃度が 3〜15\%の条件にて行われ，嫌気的にも好 気的にも認められない. 好気条件下ではカンピロバク ターは酸素によるストレス（以下酸素ストレス）を受け る. 酸素ストレスの主体は菌自身の代謝の過程で生じた 活性酸素と考えられるが，本菌の活性酸素に対する感受 性は著しく高い4). そのため, 家畜, 家禽, 野鳥などの腸 管に分布しているカンピロバクターは，水平伝播の際に 酸素ストレスにさらされることになり，一般的に食品や 環境中での生残率は低いと考えられている．それにもか かわらず，欧米諸国やわが国における細菌性食中毒の中 で，カンピロバクターは主要な原因菌の一つである。こ のことは，本菌はストレス下にてヒトの腸管に到達する まで生残することを示す.

本稿では, 酸素ストレス下のカンピロバクターの生残 について，これに及ぼすストレス前の菌の生息環境の影 響を調べた筆者らの研究成果を中心に紹介する。なお， カンピロバクターのストレス応答についてはいくつかの 総説がすでに発表されており6,8,14)，これらあ併せて参 照されたい。

\section{2. 酸素ストレス下での挙動}

カンピロバクター食中毒の原因菌は Campylobacter jejuni がほとんどを占める．本食中毒の原因食品として 鶏肉の重要性が指摘されているが，鶏の腸管内には $C$. jejuni が高率に保菌されており，食鳥処理場における屠 殺一解体過程で鶏肉は広く污染を受ける.ウシやブ夕も カンピロバクター（ウシは主にC. jejuni, ブタは C.

\footnotetext{
$\dagger$ 連絡先

*1 画158-8501 東京都世田谷区上用賀 1-18-1

*2 『141-0021 東京都品川区上大崎 3-14-23
}

coli）を保菌しているが，食肉店舗にてこれらの食肉の 污染はほとんど見られないのに対し，店頭における鶏肉 の污染率は著しく高い.この違いの要因の一つとして, 鶏肉がと場から店舗まで短期間で輸送されることが挙げ られる.このことから, 鶏肉に付着したC. jejuni は酸素 ストレスを受けて徐々に死滅していくが，完全に死滅す る前にヒトの腸管内にたよ゙り着くことができ，ここで増 殖を再開すると考えられる.

酸素ストレス下におけるC. jejuni の集団としての生 残の挙動は，ストレスに対して抵抗性を示す菌と，スト レスに感受性を示す菌に大別してとらえることができる (図 1). C. jejuni は活性酸素を消去する superoxid dismutase (SodB) や catalase (KatA), alkyl hydroperoxide reductase (AhpC) などの抗酸化酵素を保有してお り，これらの働きによって酸素ストレスに対して抵抗性 を発揮する ${ }^{1,2,9,10)}$. 本菌は, 好気条件下でより長く増殖 能を維持するために，その発現を誘導・促進する．この ようにして増殖能を維持できた菌は, ヒトへの感染を成 功させるうえで優位と考えられる。一方，ストレスに感 受性を示す菌では, ストレスによって受けた損傷によ り, その増殖能は低下する. この損傷の程度が大きいと 菌は死滅するが，その前の段階で宿主腸管内に到達でき た菌は，ここで適当な条件が整うことで損傷を修復し， 再び増殖能を回復すると考えられる。このストレス損傷 を受けた菌は, 英米の公的機関 (PHLS, FDA) や ISO が 規定する食品からのカンピロバクターの分離法でも, そ の回復を増菌培養時に図ることが含まれており, 食品検 査の面からも考慮すべき重要な対象とされている．これ に加えて, カンピロバクターは酸素ストレスによって生 きているが人工培地で培養できない状態 (viable but nonculturable [VNC] 状態) に移行することが指摘され ている3,11) (後述)

\section{3. 生残に及ぼす鉄の影響}

食肉を污染する前のカンピロバクターは，家畜や家禽 


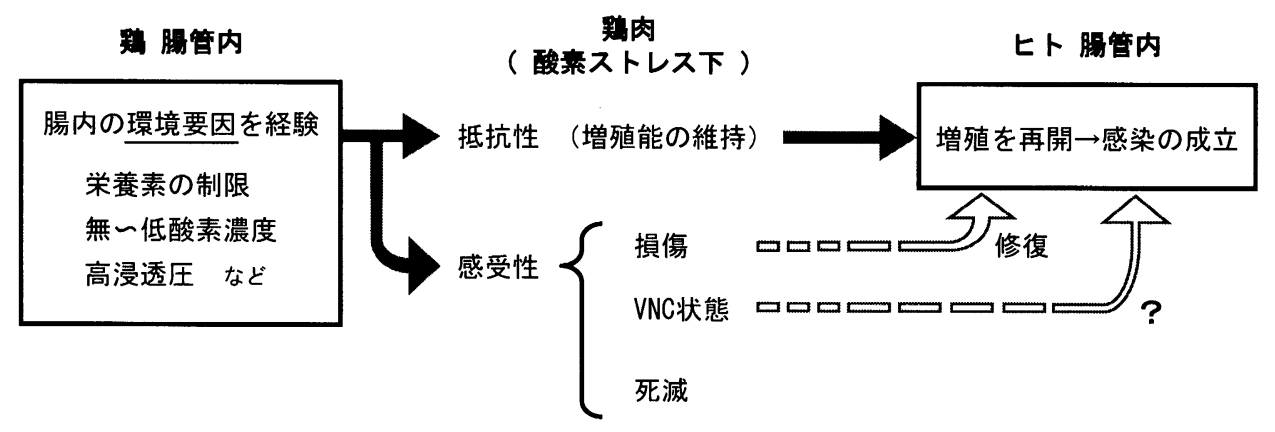

図 1. 鶏肉に付着したCampylobacter jejuni の酸素ストレス下での挙動.

の腸管内に生息している (図 1)。このことは, カンピロ バクターは腸内の環境要因 (栄養素の制限, 無〜低酸素 濃度, 高浸透圧など) を経験した後に, 酸素ストレスに さらされることを示す。しかしながら，このような環境 要因がカンピロバクターの酸素ストレス下での生残に及 ぼす影響については，ほとんど知見がない。

生物にとって鉄は生きるために必須の成分である。一 方, 動物腸管内では, 鉄は宿主が分泌する鉄結合性蛋白 質のラクトフェリンに強く結合しており，ここで生息す る細菌が利用可能な遊離鉄は制限されている ${ }^{15)}$. 前述の C. jejuni の KatA と AhpC の発現は, 転写因子 PerR に よる制御を受けて鉄制限下にて促進する13). PerR は転 写因子 Fur (ferric uptake regulator)にホモログなこと から, 細胞内の $\mathrm{Fe}^{2+}$ の増加に応じてこれ之複合体を形 成し, 制御下の遺伝子のプロモータ一付近にある特徴的 な DNA 配列 (PerR Box) に結合することで転写を制御 すると考えられている. KatA と AhpC の場合, PerR は repressor として機能しており, $\mathrm{Fe}^{2+}$ の制限によっ て各々のプロモーター領域からはずれ, 転写を誘導す る. そこで, C. jejuni をあらかじめ鉄制限下にて培養し た後に, 通常の培養を施した菌では致死的な過酸化水素 $\left(\mathrm{H}_{2} \mathrm{O}_{2}\right)$ ストレスを与えた。 その結果, 鉄制限下にて培養 した菌は, KatA と AhpC の発現を転写レベルで促進 し，ストレスに対して生残した。この結果は，あらかじ め抗酸化酵素を強発現している菌体は, 酸素ストレスに 抵抗するうえで有利であることを示唆する。近年, 腸内 に生息する C. jejuni の生理状態について, ウサギ腸管 ループ試験と DNA マイクロアレイを組み合わせて調ベ られた研究が報告され, in vivo で抗酸化酵素の発現の促 進が確認された ${ }^{12)}$.これらのことから，動物腸内で鉄制 限という環境要因を経験することは, カンピロバクター か酸素ストレスに対する抵抗性を高めるうえで重要な過 程になっていると思われる。

\section{4. 生残に及ぼす嫌気処理の影響}

これまでのC. jejuni の酸素ストレス応答に関する研 究のほとんよ゙は, 微好気条件下にて培養した菌にストレ スを与えて行われてきた。 しかしながら, 動物の腸内に は大腸のように酸素濃度が極めて低い場所があり，この

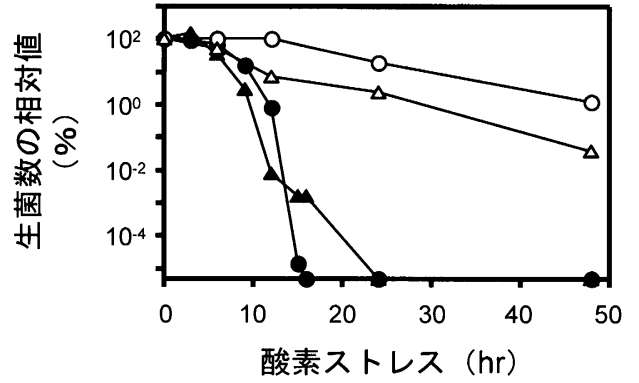

図 2. Campylobacter jejuni の酸素ストレス下での生残に 及ぼす微好気 $(\mathbf{O})$ または嫌気 $(\boldsymbol{\Delta})$ 条件下での前処 理の影響. それぞれ微好気 $(\bigcirc)$ または嫌気 $(\triangle)$ 培養 を続けた場合をコントロールとした（文献 16 より 改変).

ような嫌気的な環境中で生存した菌についてあストレス 応答に関する知見を得ることは重要である。そこで， $C$. jejuni を嫌気または微好気条件下にて処理した後, 各々 の菌に酸素ストレスを与えて生菌数の変化を比較した. その結果, 嫌気処理した菌のコロニー形成能は, ストレ スによって検出限界以下にまで減少するむのの, 微好気 処理した菌よりあ長く維持された（図 2). さらに，ス卜 レス後の菌体構成成分（DNA, RNA，蛋白質）を解析し た結果, 微好気処理した菌体で起こったストレスによる これらの著しい崩壊・減少は, 嫌気処理した菌体では確 認されなかった（図 3).これらの結果は, 嫌気処理した C. jejuni では微好気培養した菌とは異なる酸素ストレ 又応答が存在する可能性を示唆するとともに, カンピロ バクターの酸素ストレス下での生残には，ストレスを受 ける前に生育した環境中の酸素濃度が重要な役割を果た していることを示唆する.

\section{5. 形態の球状化}

カンピロバクターの形態は, 生育に不利な環境に移す ことで, らせん状桿菌から球状に変化する. この形態の 菌体は人工培地では增殖できないが, 再びらせん状に戻 り增殖能を回復する VNC 状態である可能性を持つこと から か $^{3,11)}$, 食品の安全性を確保するうえで重要性が指摘 されている. しかし，これらの可能性については科学的 な知見が乏しく，明らかとなっていない，酸素ストレス は C. jejuni の球状化を促す要因の一つであることから, 


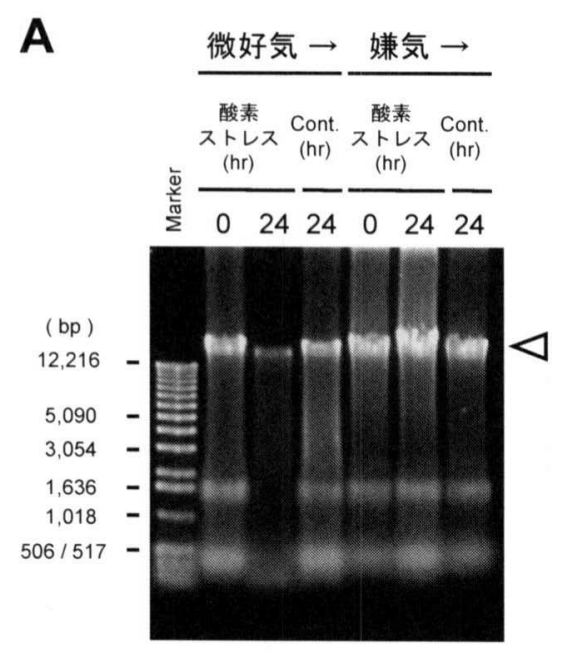

B

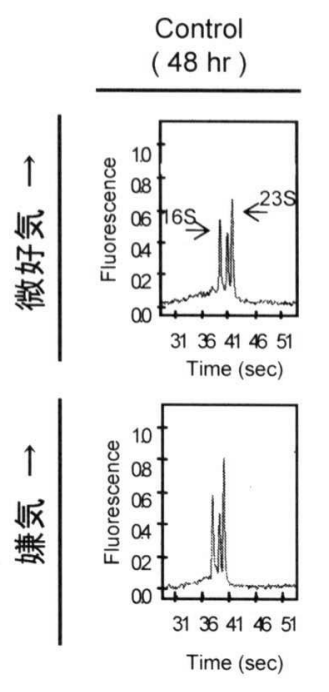

酸素ストレス ( $48 \mathrm{hr}$ )
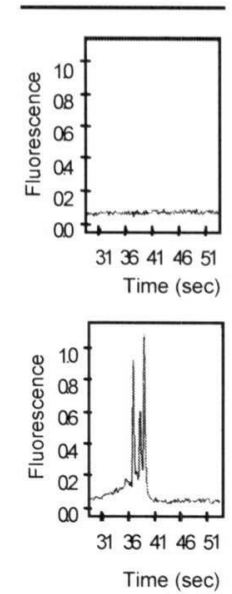

C
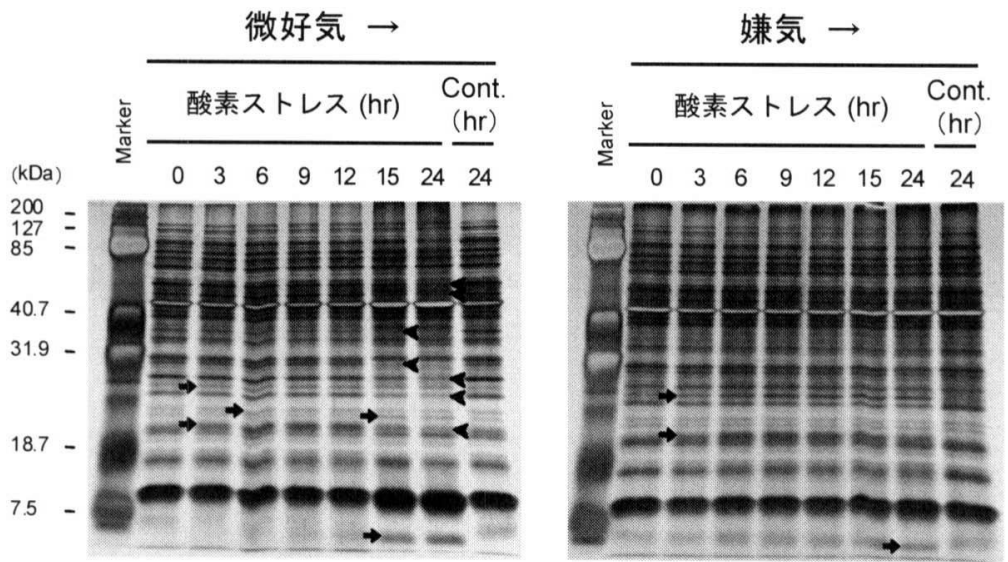

図 3. 酸素ストレス下におけるCampylobacter jejuni の菌体構成成分 DNA (A), RNA (B) および蛋白質 (C) に及ぼす微好気ま たは嫌気処理の影響. 白い矢頭は intactな DNA を示す。黒い矢印は発現が増加した蛋白質を，黒い矢頭は減少した蛋 白質を示す (文献 16 より引用).

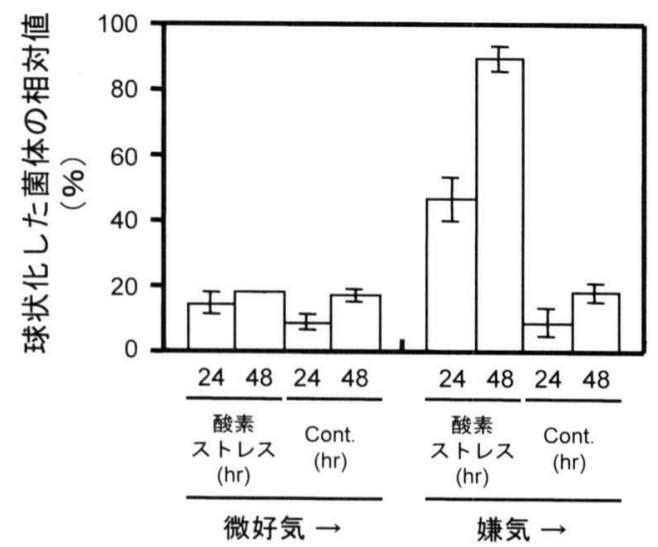

図 4.Campylobacter jejuni の酸素ストレスによる形状の 球状化に及ぼす微好気または嫌気処理の影響（文献 16 より引用)。

ストレス後の前述の各菌体の形態を観察した。 その結 果, 微好気処理した菌体は酸素ストレスによる形態変化 が起こらなかったのに対して, 嫌気処理した菌体ではス トレスによる球状化が顕著であった（図 4).ところで, われわれの結果と異なり, 他の報告では, 微好気処理し
た菌でも酸素ストレスによる球状化が確認されてい $ろ^{3,5)}$. このとき, 細胞質成分や DNA 量の著しい減少が 認められているが, このような状態は菌に致死的な影響 を及ぼしていると思われる，一方，嫌気的な環境を経験 した後にストレスを受けた菌は, その構成成分の崩壊・ 減少を最小限にとどめて球状化した。 今後さらに実証的 な証明が必要であるが, カンピロバクターが構成成分の 減少を最小限にして球状化することは，この菌体が再び 増殖能を回復する場合に強く影響する要因の一つになる と思われる. また, 微好気処理した菌が球状化しなかっ たというわれわれの実験結果は, ストレスによって著し く減少した蛋白質の中に, 形態变化にかかわる分子が存 在するという仮説をむたらす。最近，われわれは減少し た蛋白質の一つを同定し, これが C. jejuni の主要抗原 の一つであることを明らかにした（Yamasaki et al., 論 文投稿隼備中). その後の解析結果から, 本蛋白質はペプ チドグリカン分解活性を持つことが示唆された.このこ とから, 今後, 本蛋白質の機能を詳細に解析することで, 球状化のメカニズムの一端が明らかになることが期待さ れる. 


\section{6. ま と め}

宿主腸管内に生息しているC. jejuni は, これまで実 験室で調製されてきた菌体（微好気培養した菌体）と比 べると, 酸素ストレス下でより長く生残できるようであ る.さらに, 腸内環境を経験したことは, 本菌の形態の 球状化の過程です強く作用し，ストレスによる障害を最 小限にとどめる。このような状態で球状化した菌体は, これまでに用いられてきた菌体と大きく異なり, 再び増 殖能を回復する可能性が強く示唆される. 今後, この菌 体を用いて, 本食中毒における球状化した菌の重要性を 明らかにする必要がある。

\section{文献}

1) Baillon, M. L. A., van Vliet, A. H. M., Ketley, J. M., Constantinidou, C. and Penn, C. W.: An iron-regulated alkyl hydroperoxide reductase $(\mathrm{AhpC})$ confers aerotolerance and oxidative stress resistance to the microaerophilic pathogen Campylobacter jejuni. J. Bacteriol., 181, 4798-4804 (1999).

2) Grant, K. A. and Park, S. F.: Molecular characterization of katA from Campylobacter jejuni and generation of a catalase-deficient mutant of Campylobacter coli by interspecific allelic exchange. Microbiology, 141, 1369-1376 (1995).

3) Harvey, P. and Leach, S.: Analysis of coccal cell formation by Campylobacter jejuni using continuous culture techniques, and the importance of oxidative stress. J. Appl. Microbiol., 85, 398-404 (1998).

4) Krieg, N. R. and Hoffman, P. S.: Microaerophily and oxygen toxicity. Ann. Rev. Microbiol., 40, 107-130 (1986).

5) Moren, A. P. and Upton, M. E.: A comparative study of the rod and coccoid forms of Campylobacter jejuni ATCC 29428. J. Appl. Bacteriol., 60, 103-110 (1986).

6) Murphy, C., Carroll, C. and Jordan, K. N.: Environmental survival mechanisms of the foodborne pathogen Campylobacter jejuni. J. Appl. Microbiol., 100, 623-632 (2006).
7) Palyada, K., Threadgill, D. and Stintzi, A.: Iron acquisition and regulation in Campylobacter jejuni. J. Bacteriol., 186, 4714-4729 (2004).

8) Park, S. F.: Environmental regulatory genes. Campylobacter, 2nd Edition. Nachamkin, I. and Blaser, M. J. (eds.), p. 423-440, ASM Press, Washington, D.C. (2000).

9) Pesci, E. C., Cottle, D. L. and Pickett, C. L.: Genetic, enzymatic, and pathogenic studies of the iron superoxide dismutase of Campylobacter jejuni. Infect. Immun., 62, 2687-2694 (1994).

10) Purdy, D. and Park, S. F.: Cloning, nucleotide sequence and characterization of a gene encoding superoxide dismutase from Campylobacter jejuni and Campylobacter coli. Microbiology, 140, 1203-1208 (1994).

11) Rollins, D. M. and Colwell, R. R.: Viable but nonculturable stage of Campylobacter jejuni and its role in survival in the natural aquatic environment. Appl. Environ. Microbiol., 52, 531-538 (1986).

12) Stintzi, A., Marlow, D., Palyada, K., Naikare, H., Panciera, R., Whitworth, L. and Clarke, C.: Use of genome-wide expression profiling and mutagenesis to study the intestinal lifestyle of Campylobacter jejuni. Infect. Immun., 73, 1797-1810 (2005).

13) van Vliet, A. H. M., Baillon, M. L. A., Penn, C. W. and Ketley, J. M.: Campylobacter jejuni contains two Fur homologs: Characterization of iron-responsive regulation of peroxide stress defense genes by the PerR repressor. J. Bacteriol., 181, 6371-6376 (1999).

14) van Vliet, A. H. M., Ketley, J. M., Park, S. F. and Penn, C. W.: The role of iron in Campylobacter gene regulation, metabolism and oxidative stress defense. FEMS Microbiol. Rev., 26, 173-186 (2002).

15) 山本重雄, 篠田純男: 病原菌の鉄獲得機構. 日本細菌学 会誌, 51, 523-547 (1996).

16) Yamasaki, M., Igimi, S., Katayama, Y., Yamamoto, S. and Amano, F.: Effects of anaerobic preculture on aerobic stress responses of Campylobacter jejuni. Bioscience Microflora, 22, 21-25 (2003). 


\title{
シンポジウムロCampylobacter 食中毒の制御
}

- Control of Campylobacter Food Poisoning

\section{家畜衛生分野におけるカンピロバクターの耐性菌の現状}

Trends in Antimicrobial Resistance in Campylobacter Isolates from Food-Producing Animals

\author{
原田和記 \\ （農林水産省動物医薬品検査所） \\ Kazuki HARADA
}

(National Veterinary Assay Laboratory, Ministry of Agriculture, Forestry and Fisheries, 1-15-1 Tokura, Kokubunji, Tokyo 185-8511)

\section{1.はじめに}

人の腸炎の起因菌となるカンピロバクターは, 家畜・ 家舍に対して病原性を示すことなく，腸管内に分布して いる. そのため, 通常, 動物用抗菌性物質製剂（抗菌剂） がカンピロバクターの制御のために使用されることはな いが，抗菌剤が食用動物のさまざまな疾病の治療のため に使用されてきた過程で，カンピロバクターが抗菌剤に 対する耐性を獲得してきた可能性を否定することはでき ない，近年，薬剤耐性カンピロバクターに関する国際的 に最も注目されている話題として，米国における家离用 フルオロキ/ロン $(\mathrm{FQ})$ 剂（飲水添加剤：品名「バイトリ ル液」）の承認取り消しが挙げられよう。この問題は, 2000 年末の米国食品医薬品庁 (FDA) による最初の勧告 以降，米国製薬業界（バイエル社）や獣医師会などとの 間でさまざまな論議が繰り広げられてきたが，ついに 2005 年 7 月末に FDA コミッショナーの最終裁定が下 された（2005 年 9 月施行）。この承認取り消しの過程 で，(1)米国においては，人のカンピロバクター腸炎が細 菌性腸炎の中で最も発生頻度が多く（年間患者数約 10,000 人), また，年間死亡者数も約 100 人と重篤にな ることがあること蚆，(2)1995 年に獣医療用に FQ 剂が 認可・導入された以降，カンピロバクタ一腸炎患者由来 株, 食品由来株および家畜由来株の $\mathrm{FQ}$ 耐性率が増加傾 向にあること ${ }^{14)}$, (3)カンピロバクターを腸管内に定着さ せた鶏を用いた耐性獲得試験において, 本剤投薬後は速 やかに FQ 耐性株が高率に出現すること ${ }^{11)}$, (4)本症の原 因食品のほとんどが鶏肉であること5) および(5)本症に対 する治療の第二次選択薬が $\mathrm{FQ}$ 剂であり, その起因菌が 而性化することで人での治療が困難となり ${ }^{2)}$, 本事象は 人の健康にとって大きな劦威となることなどに関しての

\footnotetext{
$\dagger$ 連絡先

区181-0011 東京都国分寺市戸倉 1-15-1
}

定性的リスク評価が行われている.

そこで，本稿では，このようなカンピロバクターの $\mathrm{FQ}$ 耐性を巡る最近の国際情勢などを踏まえて, わが国 の家畜衛生分野における薬剤耐性カンピロバクタ一の現 況などについて概説したい.

\section{2. カンピロバクターにおける重要な薬剤耐性および それらに対応する動物用抗菌剂の使用状況}

人のカンピロバクター症のうち, 特に重症患者は, マ クロライド $(\mathrm{ML})$ 系薬剤やフルオロキノロン $(\mathrm{FQ})$ 系薬 剂などの抗菌薬で治療される。このため, カンピロバク ターでこれらの薬剤に対する耐性株が増加すると治療効 果などに影響する可能性がある。

現在, ML 系動物用抗菌剤として, エリスロマイシン, スピラマイシン，タイロシン，ジョサマイシン，チルミ コシン，テルデカマイシンおよびミロサマイシンの 7 成 分各々を含む製剤が承認されている，牛では細菌性肺炎 および乳房炎を適応症とした注射剂, 飲水添加剂および 乳房注入剂が, 豚では細菌性肺炎, 豚丹毒および細菌性 下痢を適応症とした注射剂, 飲水添加剂および飼料添加 剂が，鶏では伝染性コリーザおよび呼吸器性マイコプラ ズマ病を適応症とした注射剂, 飲水添加剂および強制経 口投与剂がそれぞれ使用されている。また，タイロシン については抗菌性飼料添加物（食用動物の発育促進およ び飼料効率の改善などを期待して低濃度で飼料に添加さ れ，比較的長期間にわたり使用されるもの）としても用 いられている.

一方, 動物用 $\mathrm{FQ}$ 系抗菌剤としては, ダノフロキサシ ン, エンロフロキサシン, オルビフロキサシン, ジフロ キサシンおよびノルフロキサシンの 5 成分各々を含む 製剂が承認されている，牛では肺炎および大腸菌性下痢 を適応症とした強制経口投与剂および注射剂が，豚では 細菌性下痢，マイコプラズマ性肺炎および胸膜肺炎を適 応症とした飲水添加剤，飼料添加剂および注射剂が，鶏 


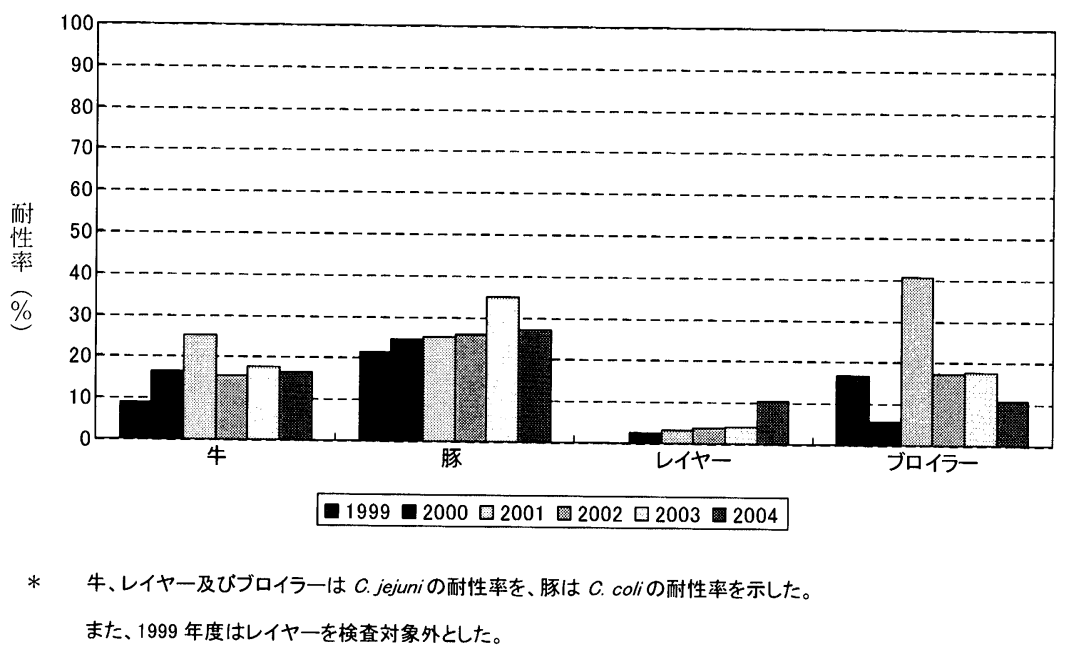

図 1. 近年における健康家畜由来カンピロバクターのエンロフロキサシン耐性率.

では大腸菌症および呼吸器性マイコプラズマ病を適応症 とした飲水添加剤がそれぞれ使用されている。このよう に ML および $\mathrm{FQ}$ 系薬剤は, 人のカンピロバクター症の 治療薬であるとともに，畜産上の重要な抗菌剤としても 位置づけられる，食用動物に ML 系および $\mathrm{FQ}$ 系抗菌剂 を含む動物用抗菌剤を投与することにより, カンピロバ クターなどの食中毒菌が薬剤耐性化し, 食品および畜産 物を介して人の健康に及ぼすリスクは, 食品安全基本法 に基づき農林水産省が食品安全委員会に諮問しており, 現在, 食品健康影響評価が実施されているところであ る.

\section{3. 家畜衛生分野における薬剤耐性モニタリング体制 (JVARM)}

$\mathrm{ML}$ 系および $\mathrm{FQ}$ 系抗菌剂を含む動物用抗菌剂をめぐ る世界的な動きとして，世界保健機関 (WHO) は，食用 動物へ抗菌性物質を使うことにより出現した薬剤耐性菌 （およびその遺伝子）が食物連鎖を介して人へ伝播し，人 の細菌感染症の治療を困難にするという危険性について 議論するため, 1997 年 10 月にWHO が「食用動物にお ける抗菌性物質の使用が人に医療に及ぼす影響」につい ての専門家会議をべルリンで開催した。 それ以降, WHO, 国際獣疫事務局 (OIE) および国際連合食糧農業 機関 $(\mathrm{FAO})$ の主催する種々な国際会議の中で，カンピ ロバクターを含む食品媒介性病原菌の薬剤耐性が動物之 人との間でどの程度発現し，拡散しているかとの疫学的 な知見を得るための国家レベルでの耐性菌の動向調査の 重要性や国際的なネットワークの構築などが議論されて きた。

このような背景から, 農林水産省の動物用医薬品危機 管理対策事業の一環として，1999 年度の予備調査を経 て 2000 年度以降, 都道府県の家畜保健衛生所と動物医 薬品検査所とのネットワークにより家畜由来細菌の薬剤 耐性モニタリング体制 (Japanese Veterinary Antimic- robial Resistance Monitoring System; JVARM) が構 築された ${ }^{16)}$. 本調査では食品媒介性病原菌として，今回 のテーマであるカンピロバクターのほかにサルモネラ を, 薬剤感受性の指標菌として腸球菌と大腸菌を対象と している.

\section{4. 各国および日本の家畜分野における薬剤耐性カン ピロバクターの出現動向}

\section{1) FQ 系薬剂耐性}

スペインで 1997〜1998 年に行われた調査によると, $\mathrm{FQ}$ 耐性率は, 肉用鶏 (ブロイラー) 由来 Campylobacter jejuni で 98.7\%，また，豚由来 C. coli では 100\%であっ た ${ }^{13)}$. ドイッでは, 2001 年の家昺由来 C. jejuni で 42.0\%, C. coli で 70.6\%であった ${ }^{9)}$. また, デンマーク (DANMAP) では, 2004 年の牛由来 C. jejuni で $2 \%$, ブ ロイラー由来 C. jejuni で $5 \%$ および豚由来 C. coli で 16\%であった ${ }^{3)}$. アメリカ (ワシントン州)では, 2002〜 2003 年の牛由来 C. jejuni で $5.1 \%$, 牛由来 C. coli で 45.5\%と報告されている11. このように, 各国間で食用動 物に打ける $\mathrm{FQ}$ 耐性カンピロバクターの出現状況は異 なっている，一方，日本では，JVARM 当初（1999〜 2000 年度）の成績では牛由来 C. jejuni で $13.0 \%$ ，ブロ イラー由来 C. jejuni で $12.0 \%$, 採卵彩（レイヤー）由来 C. jejuni で $2.6 \%$ および豚由来 C. coli で $23.4 \%$ となっ ており ${ }^{6)}$ ，その後の成績も含めた 6 年間（1999～2004 年度の成績，ただしレイヤーのみ 2000〜2004 年度の 5 年間の成績）の平均耐性率は, 牛由来 C. jejuni で $16.6 \%$, ブロイラ一由来 C. jejuni で $18.1 \%$, レイヤー由 来 C. jejuni で $4.8 \%$ および豚由来 C. coli で $26.2 \%$ であ り, 年度により若干の差が認められるものの, ほぼ一定 の推移を保っている. また, 動物種間の体制率の比較で は，一般的に，レイヤ一由来株で低く豚由来株で高い傾 向が認められている(図 1). 


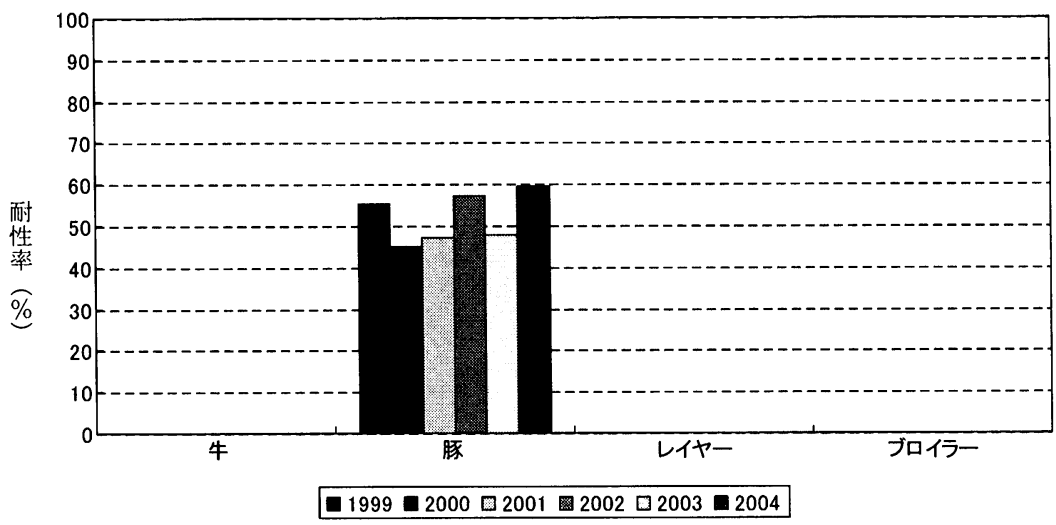

* 牛、レイヤー及びブロイラーは $C$. jejuniの酎性率を、䀠は C. coliの耐性率を示した。 また、1999 年度はレイヤーを検查対象外とした。

図 2. 近年における健康家畜由来カンピロバクターのエリスロマイシン耐性率.

\section{2) ML 系薬剂耐性}

ML 而性は，スペインで 1997〜1998 年に行われた調 査によれば, 豚由来 C. coli で $81.1 \%$ であり, ブロイラー 由来株では C. jejuni / coli 共に 0\%であった ${ }^{13)}$. また, DANMAP では, 2004 年のブロイラー由来C. jejuni で $1 \%$, 牛由来 C. jejuni で $0 \%$, 豚由来 C. coli で $23 \%$ と報 告されている31.アアメリカ（ワシントン州）の牛由来株で はC. jejuni で $2.9 \%$, C. coli で $31.8 \%$ とされている11. 日本では過去 6 年間の平均耐性率は豚由来 C. coli で $52.0 \%$ あった。なおこれまでの JVARMにおいて は, ML 而性 C. jejuni は全く認められていない（図 2).

\section{3）食用動物における抗菌薬の使用状況とカンピロバ クター菌の薬剂耐性率}

日本を含む各国におけるカンピロバクターの薬剤耐性 率には異なった傾向が認められている。特に，FQ耐性 率については，各国における抗菌性物質の使用量，承認 時期，承認されている用法用量などが関与している可能 性が考えられる. 国内において動物用 $\mathrm{FQ}$ 剂は, 1992 年 に鶏呼吸器性マイコプラズマ病や鶏大腸菌症の蔓延やそ れに伴う甚大な経済的損失に対する防疫対策などを目的 として導入された，FDA が承認取り消しの対象とした 「バイトリル液」においても, 国内でむ䳕用に承認されて いるが，米国 (50 ppm, 5 日間) や $\mathrm{EU}(10 \mathrm{mg} / \mathrm{kg}, 3$ 10 日間) での承認用量より日本 $(50 \mathrm{ppm}, 3$ 日間) では 制限されており，Takahashi らの報告15) では，前述の in vivo 耐性獲得試験における $\mathrm{FQ}$ 耐性株の選択頻度や 出現パターンは必ずしあ既報8,10,11,18) とは同等ではない ことが明らかとなってきている，上述のとおり，他国に 比べ日本では $\mathrm{FQ}$ 剤の用法・用量が制限されていること が，日本の FQ 剂の使用量が比較的多いにもかかわら ず，低い FQ 耐性率で保たれている理由の一つかむしれ ない.

また，JVARMにおいて得られた知見として，FQ系 および ML 系薬剂を含む抗菌性物質の菌分離前 6 力月

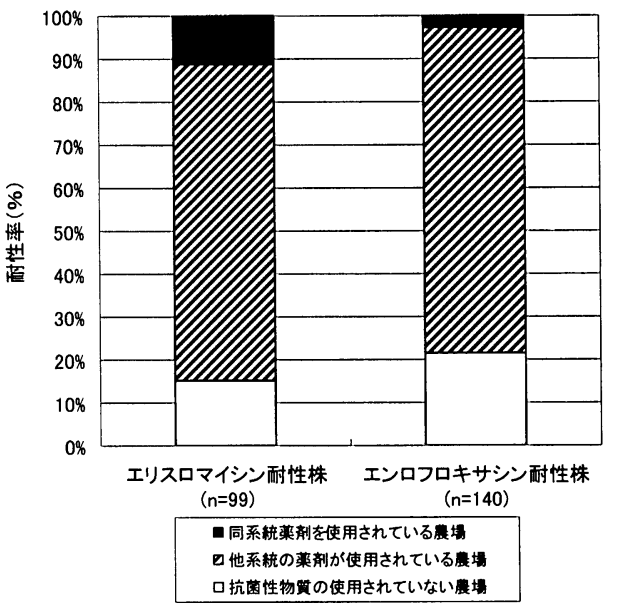

図 3. 薬剂而性カンピロバクター分離農場における抗菌性 物質の使用状況 (2001 2003).

間の投薬歴とこれらの薬剤に対する耐性菌の分布が，農 場レベルで必ずしも一致しないことが挙げられる（図 3).この点に関しては，(1)分離前 6 力月間より以前に $\mathrm{FQ}$ 系または ML 系薬剤を使用した際に，これらの薬剤 に対する而性菌が出現し，農場に定着し続けている，(2) これらの薬剤耐性菌が外部より侵入し，農場に定着して いる，(3これらの薬剤而性株が多剂耐性化し，他系統の 薬剂により共選択されている，などの現象が生じている 可能性が考えられる．薬剤而性カンピロバクターの出現 およびその制御に関しては，これらの結果を踏まえたう えでの十分な検討が必要である.

\section{5. 人症例由来株および家畜由来株の血清学的および 分子疫学的比較解析 ${ }^{7)}$}

C. jejuni においては，エンロフロキサシン (ERFX) 耐 性率は人, 牛およびブロイラ一由来株で同様の傾向を示 したが，䳕由来株中のアンピシリン (ABPC) 耐性率は, 人および牛由来株と比較して有意に低かった（図 4). Penner 法による血清型別では，血清型 $\mathrm{B}$ 抢よび D 群は 


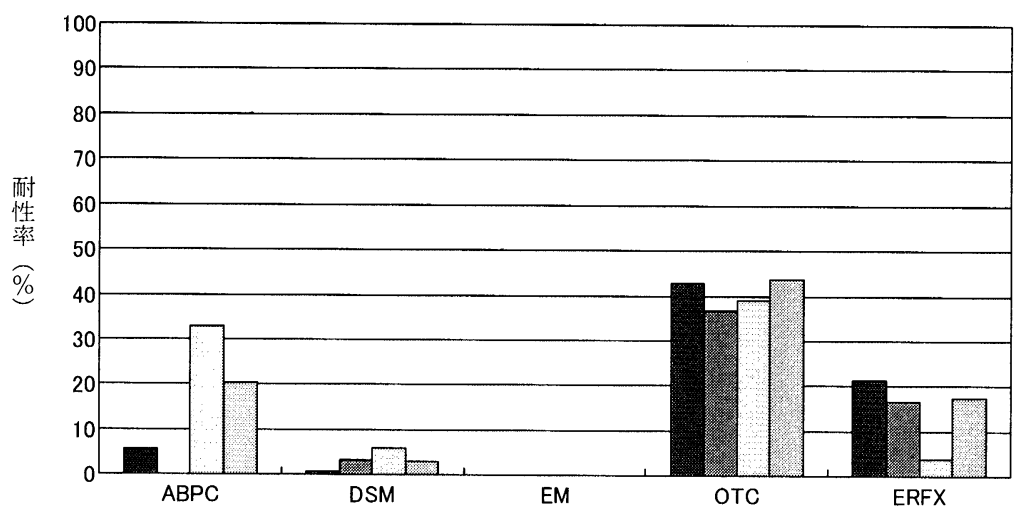

圆人圆牛ロレイヤーロブロイラー

図 4. 人および家畜由来 C. jejuni の薬剤而性率の比較.

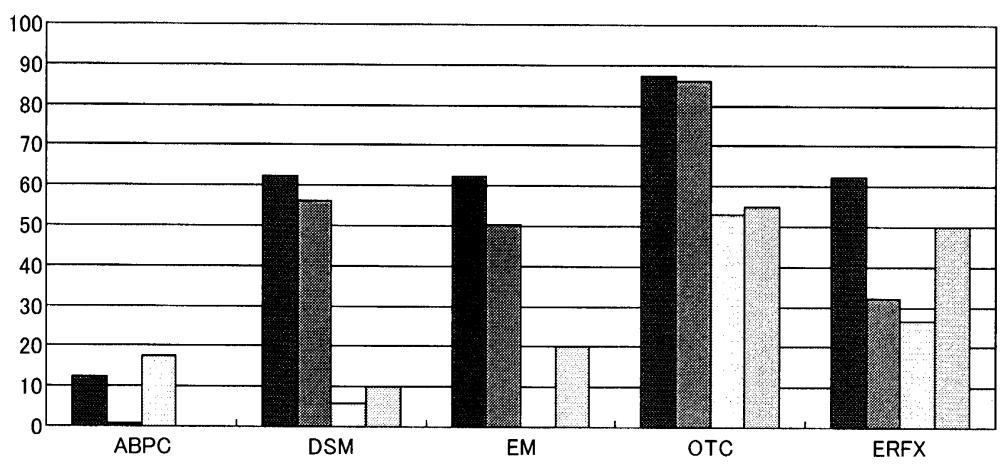

回人回豚ロレイヤーロブロイラー

図 5. 人扰よび家畜由来 $C$. coli の薬剤而性率の比較.

表 1. 日本における豚由来エリスロマイシン耐性カンピロバクターのマクロライド系薬剤抢よびリンコマイシンの MIC 分布

\begin{tabular}{|c|c|c|c|c|c|c|c|c|c|c|c|c|c|c|}
\hline \multirow{2}{*}{$\begin{array}{l}\text { Antimicrobial } \\
\text { agents }^{\text {a) }}\end{array}$} & \multirow{2}{*}{$\begin{array}{c}23 \mathrm{~S} \text { rRNA } \\
\text { mutation }\end{array}$} & \multicolumn{13}{|c|}{$\mathrm{MIC}^{\mathrm{b})}(\mathrm{mg} / \mathrm{l})$} \\
\hline & & 0.25 & 0.5 & 1 & 2 & 4 & 8 & 16 & 32 & 64 & 128 & 256 & 512 & $>512$ \\
\hline \multirow{2}{*}{$\operatorname{EM}(14)^{\mathrm{c})}$} & $\mathrm{WT}^{\mathrm{d})}$ & 1 & 3 & 4 & 13 & 3 & 4 & & & & & & & \\
\hline & A $2075 \mathrm{G}$ & & & & & & & & & & 2 & 3 & 17 & 22 \\
\hline \multirow{2}{*}{$\mathrm{AZM}(15)$} & WT & 6 & 12 & 5 & 5 & & & & & & & & & \\
\hline & A2075G & & & & & & & & & & & & 2 & 42 \\
\hline \multirow{2}{*}{ TS (16) } & WT & & & & 4 & 4 & 16 & & 4 & & & & & \\
\hline & A2075G & & & & & & & & & & 1 & & 9 & 34 \\
\hline \multirow{2}{*}{ LCM } & WT & & & & & 5 & 5 & 11 & 6 & 1 & & & & \\
\hline & A2075G & & & & & & & & & & 1 & 7 & 12 & 24 \\
\hline
\end{tabular}

a) EM, erythromycin; AZM, azithromycin; TS, tylosin; LCM, lyncomycin.

b) MIC, minimum inhibitory concentration.

c) マクロライド系薬剤の員環数.

d) WT, Wild type.

人, 牛および鶏由来で多く認められ, 血清型 $\mathrm{O}$ および $\mathrm{R}$ 群は人と牛由来株で認められた. C. coliでは, ジヒドロ ストレプトマイシン (DSM), オキシテトラサイクリン (OTC) およびエリスロマイシン (EM) 耐性に関しては, 人と豚由来株で同様の傾向を示した (図 5). カンピロバ クター属の薬剂耐性型, C. jejuni の血清型別, 鞭毛蛋白 遺伝子型によるクラスター分類の結果 (C. jejuni の人之 牛由来株に共通のクラスターが存在）から, 人症例由来 株は鷂由来株だけでなく, 牛および豚由来株とも類似し
た性状を示すことが明らかとなった。

\section{6. 豚由来 ML 耐性株の性状 4$)$}

JVARM においては, ML 而性株は C. coli 特に豚由来 株に多く認められている. そこで近年 (2004 年) に分離 された豚由来 $C$. coli を対象にその耐性機構について検

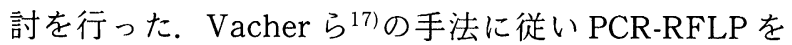
行ったところ, すべての EM 耐性株で $23 \mathrm{~S}$ rRNA 遺伝 子の 2075 位におけるアデニンからグアニンへの点変異 
(A2075G) が認められた。一方で，EM 感受性株では本 変異は認められなかった。 また, EM 而性株は, 他の ML 系薬剤であるアジスロマイシン（15 員環 ML）および夕 イロシン（16 員環 ML）ならびにリンコマイシンに対し て高い MIC 值を示した（表 1). 以上の結果から，豚由 来 EM 耐性 C. coli 株は, 23S rRNA 遺伝子の A2075G 変異を耐性機構としており，また，本変異により広い交 差耐性を獲得することから, ML 耐性 C. coli の制御のた めに交差耐性を示す関連薬剂の慎重使用が重要であるこ とが明らかとなった。

\section{7. おわりに}

最後に，薬剤耐性カンピロバクターの制御を含む食用 動物由来薬剂耐性菌のリスク管理の現状および課題につ いて言及したい.

現状ではリスク管理機関である農林水産省として，す べての抗菌剂を対象に(1)薬剂耐性菌に留意した抗菌剤の 承認審查，(2)製造販売後調查における抗菌剤の安全性の 評価，薬事法および獣医師法に基づいた抗菌剤を含む動 物用医薬品の適正使用の徹底なよ゙の対策を行っている. さらに，FQ剂などの人の臨床上も重要な抗菌剤につい ては，第一次選択薬が無効な症例に使用する第二次選択 薬であること, 薬剤感受性試験後の使用および必要最小 限の使用にとどめるなどの旨の使用上の注意への記載, および製造販売後の耐性菌の発現状況の詳細な調查の動 物用医薬品製造販売業者への義務づけなどのリスク管理 を行っている.

リスク管理を行ううえで $\mathrm{FQ}$ 剂の使用は $\mathrm{FQ}$ 耐性カン ピロバクターの出現に関与することを認識しなければな らない．しかし，一方で，FQ剤は人医療だけでなく，獣 医療においても重要な医薬品であり，今後ともその使用 は必要とされる。

これらの点を総合的に判断して，さらなるリスク管理 措置の一つとして,「カンピロバクタ一污染農場での使 用の制限」に関する内容を $\mathrm{FQ}$ 剂の使用上の注意に付け 加えることなどによりカンピロバクター保菌動物への使 用を制限する必要があると考えられる15)，その場合，食 用動物を対象とする $\mathrm{FQ}$ 風の主たる適応症である大腸菌 症およびマイコプラズマ感染症については，代償的な他 系統の抗菌剤の使用量の増加が懸念される．鶏の大腸菌 症から分離される病原性大腸菌に関しては近年の広範な 調查報告はないが，一般的な代替薬として想定される抗 菌剤には，サルファ・トリメトプリム合剤などが挙げら れる. 一方，マイコプラズマ感染症に関しては，代替抗 菌剂としては夕イロシンやジョサマイシンなどの ML 系抗菌剤が挙げられる。しかし，カンピロバクターの薬 剂耐性を考慮した場合，これらの ML系薬剤に対する耐 性獲得は, 前述のと抢り人医療での第一次選択薬である エリスロマイシンとの交差耐性につながるため，望まし い代替抗菌剤の選択とは言えないことも事実である。こ
のように，代替薬の選択については，多方面にわたる問 題を考慮して獣医師を啓蒙しなければならない.

われわれは，今後とも継続的な薬剂耐性モニタリング を実施し，そのデータなどを基に，カンピロバクターを 含む薬剤耐性菌に関するリスク分析に資する科学的知見 を提供していきたい，今後は，食品安全委員会の評価結 果如何により，適宜リスク管理措置を見直すこととなる が，食用動物における抗菌剤の慎重使用を普及および徹 底させることにより食用動物由来薬剤耐性カンピロバク ターのコントロールに寄与していきたいと考えている.

\section{文献}

1) Bae, W., Kaya, K. N., Hancock, D. D., Call, D. R., Park, Y. H. and Besser, T. E.: Prevalence and antimicrobial resistance of thermophilic Campylobacter spp. from cattle farms in Washington State. Appl. Environ. Microbiol., 71, 169-174 (2005).

2) Engberg, J., Aarestrup, F. M., Taylor, D. E., GernerSmidt, P. and Nachamkin, I.: Quinolone and macrolide resistance in Campylobacter jejuni and C. coli: resistance mechanisms and trends in human isolates. Emerg. Infect. Dis., 7, 24-34 (2001).

3) Emborg, H., Larsen, P. B., Heuer, O. E., Jensen, V.F. Hammerum, A. M., Bagger-Skjøt, L., Brandt, C., Frimodt-Møller, N. and Monnet, D. L.: Use of antimicrobial agents and occurrence of antimicrobial resistance in bacteria from food animals, foods and humans in Denmark. DANMAP 2004. Heuser, O. E. and Larsen, P. B. (eds.), p. 40-43, Dansih Inst. Food Vet. Res., Danish Zoonosis Centre. (2004).

4) Harada, K., Asai, T., Kojima, A., Sameshima, T. and Takahashi, T.: Characterization of macrolideresistant Campylobacter coli isolates from foodproducing animals on farms across Japan during 2004. J. Vet. Med. Sci 68: 1109-1111 (2006).

5) Harris, N. V., Weiss, N. S. and Nolan, C. M.: The role of poultry and meats in the etiology of Campylobacter jejuni/coli enteritis. Am. J. Public Health, 76, 407-411 (1986).

6) Ishihara, K., Kira, T., Ogikubo, K., Morioka, A., Kojima, A., Kijima-Tanaka, M., Takahashi, T. and Tamura, Y.: Antimicrobial susceptibilities of Campylobacter isolated from food-producing animals on farms (1999-2001): results from the Japanese Veterinary Antimicrobial Resistance Monitoring Program. Int. J. Antimicrob. Agents, 24, 261-267 (2004).

7) Ishihara, K., Yamamoto, T., Satake, S., Takayama, S., Kubota, S., Negishi, H., Kojima, A., Asai, T., Sawada, T., Takahashi, T. and Tamura, Y.: Comparison of Campylobacter isolated from humans and foodproducing animals in Japan. J. Appl. Microbial., 100, 153-160 (2006).

8) Jacobs-Reitsma, W.F., Kan, C. A. and Bolder, N. M.: The induction of quinolone resistance in Campylobacter bacteria in broilers by quinolone treatment. Lett. Appl. Microbiol., 19, 228-231 (1994). 
9) Luber, P., Wagner, J., Hahn, H. and Bartelt, E.: Antimicrobial Resistance in Campylobacter jejuni and Campylobacter coli strains isolated in 1991 and 20012002 from poultry and humans in Berlin, Germany. Antimicrob. Agent Chemother., 47, 3825-3830 (2003).

10) Luo, N., Sahin, O. Lin, J. Michel L. O. and Zhang, Q.: In vivo selection of Campylobacter isolates with high levels of fluoroquinolone resistance associated with gyrA mutatuions and the function of the CmeABC efflux pump. Antimicrob. Agents Chemother., 47, 390-394 (2003).

11) McDermott, P. F., Bodeis, S. M., English, L. L., White, D. G., Walker, R. D., Zhao, S., Simjee, S. and Wagner, D. D.: Ciprofloxacin resistance in Campylobacter jejuni evolves rapidly in chickens treated with fluoroquinolones. J. Infect. Dis., 185, 837-840 (2002).

12) Mead, P. S., Slutsker, L., Dietz, V., McCaig, L. F., Bresee, J. S., Shapiro, C., Griffin, P. M. and Tauxe, R. V.: Food-related illness and death in the United States. Emerg. Infect. Dis., 5, 607-625 (1999).

13) Saenz, Y., Zarazaga, M, Lantero, M., Gastanares, M. J., Baquero, F. and Torres, C.: Antibiotic Resistance in Campylobacter Strains Isolated from Animals, Foods, and Humans in Spain in 1997-1998. Antimicrob. Agent Chemother., 44, 267-271 (2000).

14) Smith, K. E., Besser, J. M., Hedberg, C. W., Leano, F. T.,
Bender, J. B., Wicklund, J. H., Johnson, B. P., Moore, K. A. and Osterholm, M. T.: Quinolone-resistant Campylobacter jejuni infections in Minnesota, 1992-1998. Investigation Team. N. Eng. J. Med., 340, 1525-1532 (1999).

15) Takahashi, T., Ishihara, K., Kojima, A., Asai, T., Harada, K. and Tamura, Y.: Emergence of fluoroquinolone resistance in Campylobacter jejuni in chickens exposed to enrofloxacin treatment at the inherent dosage licensed in Japan. J. Vet. Med. B, 52, 460-464 (2005).

16) Tamura, Y.: The Japanese veterinary antimicrobial resistance monitoring system (JVARM). OIE International Standard Antimicrobial Resistance. Bernard, V. (eds.), p. 206-210, OIE Headquarters, Paris, France (2003).

17) Vacher, S., Ménard, A., Bernard, E. and Mégraud, F.: PCR-restriction fragment length polymorphism analysis for detection of point mutations associated with macrolide resistance in Campylobacter spp. Antimicrob. Agent Chemother., 47, 1125-1128 (2003).

18) Van Boven, M., Veldman, K. T. De, Jong M. C. M. and Mevius D. J.: Rapid selection of quinolone resistance in Campylobacter jejuni but not in Escherichia coli in individually housed broilers. J. Antimicrob. Chemother., 52, 719-723 (2003). 


\title{
シンポジウムロCampylobacter 食中毒の制御
}

Control of Campylobacter Food Poisoning

\section{カンピロバクター食中毒の発生とその対応}

Outbreaks of Campylobacter jejuni Food Poisoning and Its Prevention

\author{
品川邦汎 ${ }^{\dagger}$ \\ (岩手大学農学部獣医学科) \\ Kunihiro SHINAGAwA \\ (Department of Veterinary Medicine, Iwate University)
}

近年, 各国でヒトの下痢症・食中毒の起因菌として Campylobacter jejuni が注目されている. 特に, わが国 における食中毒発生件数では C. jejuni/coli（その多くは C. jejuni）によるものが第 1 位を占めている. しかし， これらのほとんどは夏期などに発生が多く見られる患者 1 名の散発事例である. また, 近年では集団事例（患者 2 名以上）あ増加傾向を示している.

C. jejuni 食中毒の原因食品としては, 「食鳥肉抢よび その加工品」などの食鳥肉関連食品によるものが最む多 く，その他牛肉など（牛レバー，バーベキュー）による ものも比較的多く見られる.

市販食鳥肉の本菌污染は高く, 予販品の $60 \%$ 以上が 陽性であり, 污染菌数も多いもの $\left(10^{4} \mathrm{cfu} / 100 \mathrm{~g}\right.$ 以上 $)$ あ認められている. なお, 牛レバーの C. jejuni/coli 污染 については肝臓表面のみならず, 肝臓実質 (胆汁) から あ検出されることが明らかにされている.

本菌食中毒の予防としては, 食鳥肉および牛肉などへ の C. jejuni 污染防止が最む大切であり，そのためには 食鳥処理場や之畜場での衛生的解体処理の方法を確立す ることが重要である.

本シンポジゥムでは, C. jejuni 食中毒の発生概要（原 因食品を含む), 食中毒原因食品として多い食鳥肉の本 菌污染状況, および食鳥処理場でのと殺・解体工程での 污染防止のための衛生管理 (HACCP：危害分析重要管 理点方式, SSOP: 標準的衛生作業手順書などの作成) の 方法について, さらに, 食鳥（ブロイラー）生産農場で の C. jejuni 污染状況および䳕への保菌防止などについ ても報告する。

\section{1. カンピロバクター食中毒の発生状況}

\section{1) 発生件数・患者数}

わが国における食中毒発生件数は，1997 年（平成 9 年）加患者 2 名以上の集団発生事例に加え，患者 1 名

\footnotetext{
†連絡先

焉020-8550 盛岡市上田 3-18-8
}

の散発事例む食中毒事件として届け出義務が定められ, 年間約 1,800 3,000 件（患者数は 26,000 46,000 名/ 年）と急増を示した。 これらのうち，散発事例は 860〜 1,600 件/年と食中毒総発生件数の過半数 (43〜 53\%) を 占めている. しかし，これらの散発事例はすべての自治 体（都道府県市）から届け出されているわけではなく, ある特定の自治体 (1 県・1市) からのみである。そのた め, 1998 年 (平成 10 年) の厚生労働省の食中毒発生統 計から，食中毒事件は集団事例と散発事例を区別して集 計されるようになった。

散発食中毒事件の中で C. jejuni/coli によるものが圧 倒的に多く, 1998 年から 2004 年の 7 年間では毎年 $322 \sim 490$ 件の発生を示し，全散発事件数の 30〜 38\% （C. jejuni/coli 食中毒事件の約 70〜80\%）を占めてい る. 他方, C. jejuni/coli 集団食中毒（患者発生 2 名以上 の事件) は, 年間 63〜150 件（全集団件数の 5〜17\%を 占める）の発生を示しており，しかもその発生数は年々 増加してきている．また，それらの患者数屯約 1,400〜 2,300 名/年（集団事件の総患者数の 3〜 $15 \%$ を占めて いる）と増加傾向を示している.

\section{2）食中毒原因食品}

わが国におけるC. jejuni/coli 食中毒の原因食品（散 発事例を含む）判明数は年々増加してきている．原因食 品の中で最も多いむのは「肉類およびその加工品」によ る事例であり，1998 年から 2004 年までは毎年 13〜48 件（患者数 98〜775 名）の発生が報告されている。ま た，「卵およびその加工品」および「複合調理食品」によ るものも $1 \sim 2$ 件/年発生している，このほか，原因食品 を特定することができなかったが，食品によることが明 らかにされた事例が 19〜62 件/年（患者数 400〜1,200 名/年程度）と多いことが示されている.

本菌食中毒は，食品を喫食して発症するまでの潜伏期 が比較的長く（2〜7日間), 摂食状況などの調査が困難 であり，保存食品（検食）または食べ残し品がない場合 が多い，また，集団調理・給食施設などでは食品保存が 行われていたとしても，保存期間中に菌の死滅（または 
菌数の減少）により検出が困難であり, 原因食品の特定 が難しいことが知られている. 原因食品不明の事例は, 年間約 $360 \sim 520$ 件（患者数 $800 \sim 1,100$ 名）之, $C$. $j e j u n i / c o l i$ 食中毒全件数（430～560 件/年）の $77 \sim$ 94\%を占めている.さらに, 「肉類およびその加工品」に よる食中毒原因物質（原因菌）上しては, C. jejuni/coli によるものが圧倒的に多く，事件数の 40〜 75\%（患者 数では約 $50 \%$ ）を占めており, さらに本菌事件数は年々 増加してきている。このほか, サルモネラや腸管出血性
大腸菌（0157, O26 なよ゙）による事例も比較的多く見ら れる (図 1). 他方, 患者数についてもC. jejuni/coliに よるものが最も多く, 事件数に相応して増加している. その他, サルモネラやウエルシュ菌による患者数む比較 的多い（図 1). また「肉類拉よびその加工品」による事 例では, 食鳥肉関連食品によるものが多く, C. jejuni/ coli 食中毒件数の約 4 8\%を占めている，特に，鳥肉 （鳥肉・ササミ・鳥レバーの刺身，鳥たたきなど）による 事例が多く報告されている。また，鶏肉料理およびバー
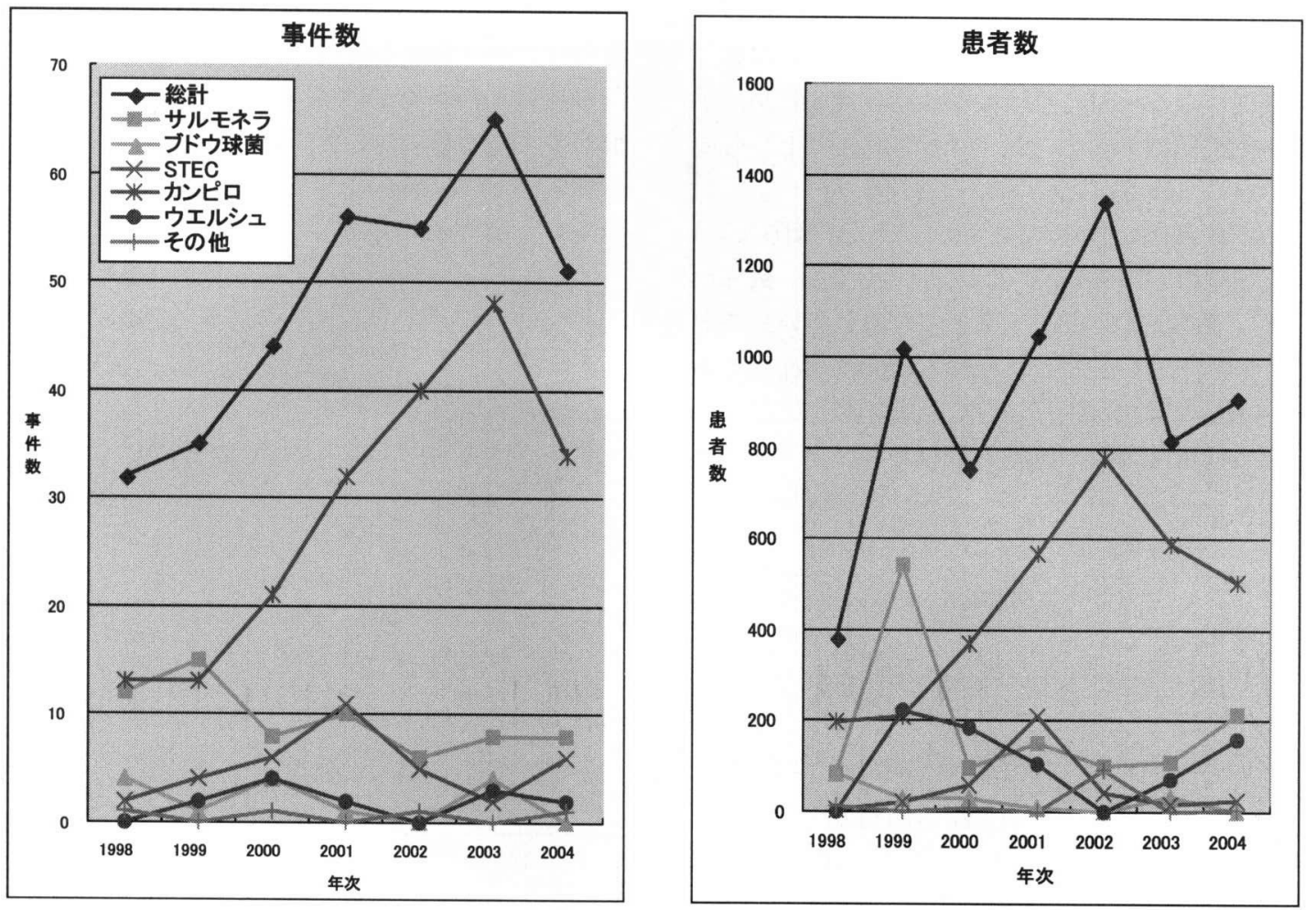

図 1. 食肉・食鳥肉およびその加工品による細菌性食中毒.

表 1. 原因食品別のカンピロバクター食中毒事件

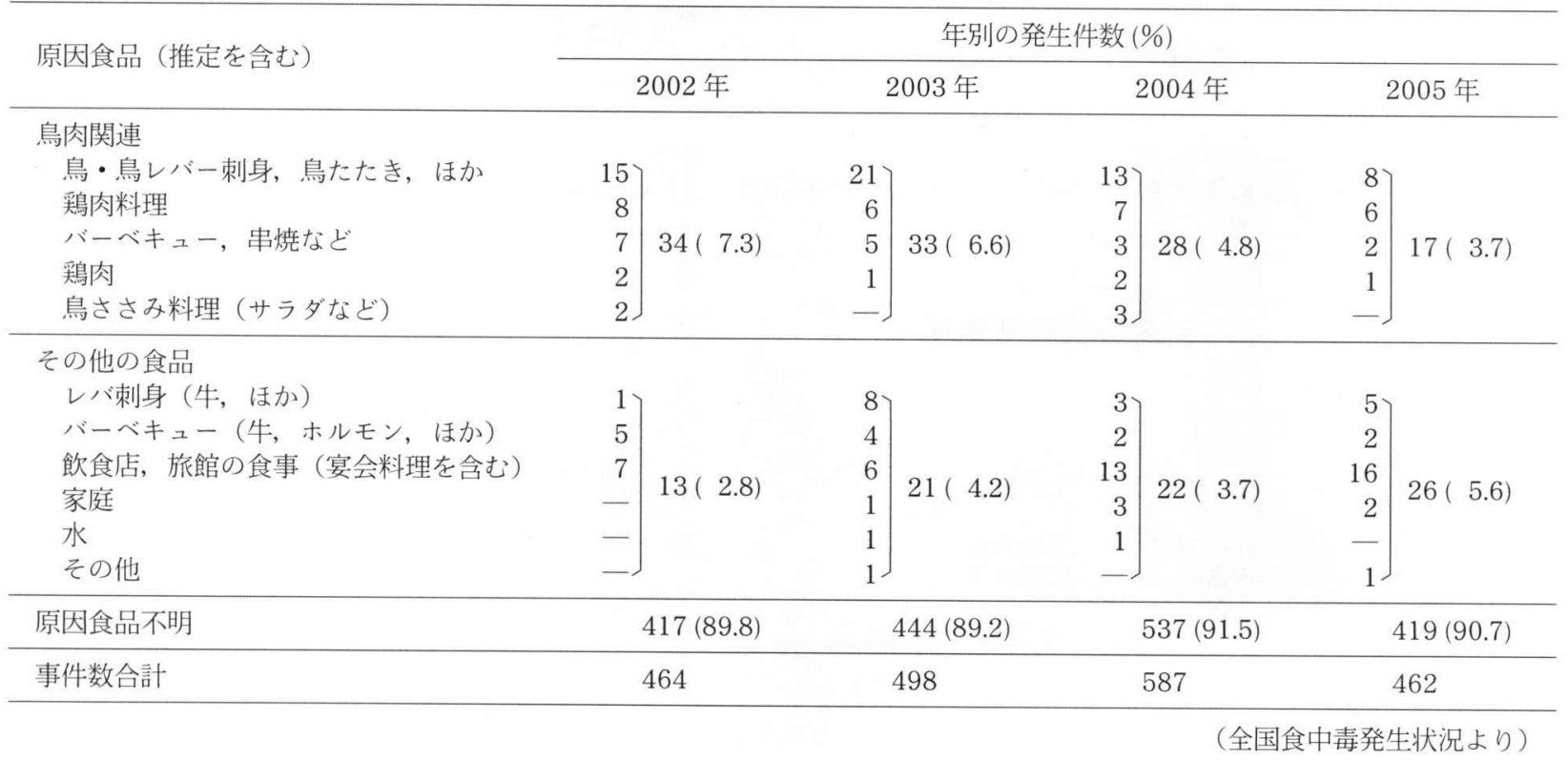


ベキュー，串焼きなどによる事例も多い。このほか，牛 レバー刺身，牛バーベキュー・ホルモンによる事例，ま た特定の食品としては究明されなかったが, 飲食店, 旅 館などの食事によることが明らになった事例む多い（表 1).

\section{2. 市販食鳥の食中毒菌污染}

市販鶏肉（屯屯肉，むね肉，手羽先などの部位）から 分離されるCampylobacter 属菌のほとんどが C. jejuni であり, その污染率は極めて高い. また, 污染菌数む 1.0 $\times 10^{2} \sim 1.0 \times 10^{3} \mathrm{cfu} / 100 \mathrm{~g}$ のあのが 50〜60\%見られ， $1.0 \times 10^{4} \mathrm{cfu} / 100 \mathrm{~g}$ 以上のものも数\%存在する.なお， 鶏肉の部位別による污染の差はあまり見られないが, 手 羽先やむね肉で菌数の多い $\left(10^{4} \mathrm{cfu} / 100 \mathrm{~g}\right.$ 以上）むの む存在している（表 2).

他方，国内産鵎肉に比べ外国（ブラジル，米国など） からの輸入鶏肉の C. jejuni 污染は低い（污染率：数\%〜 $20 \%$ ，污染菌数： $10^{2} \mathrm{cfu} / 100 \mathrm{~g}$ のあが多い）こと が示されている。しかし，これら輸入鶏肉は冷凍品であ り, 凍結・融解により本菌が凍結障害や死滅などを示 し，污染率の低下，菌数の低減を示したものと考えられ

表 2 . 市販鶏肉のカンピロバクター污染

\begin{tabular}{|c|c|c|c|c|c|}
\hline \multirow{2}{*}{ 検体名 } & \multirow{2}{*}{ 検体数 } & \multicolumn{4}{|c|}{ C. jejuni 污染菌数 (cfu/100 g) 別検体数 (\%) } \\
\hline & & $-1)$ & $10^{1}-10^{2}$ & $10^{2}-10^{3}$ & $\geqq 10^{3}$ \\
\hline 手羽先 & 46 & $18(39.1)$ & $2(4.3)$ & & $22(47.8)$ \\
\hline む权肉 & 44 & $14(3$ & $4(9.1)$ & $7(15.9)$ & $19(43.2)$ \\
\hline 屯屯肉 & 45 & $17(37.8)$ & $9(20.0)$ & $5(11.1)$ & $14(31.1)$ \\
\hline 計 & 135 & 49 (36.3) & $15(11.1)$ & 16 (11.9) & 55 (40.7) \\
\hline
\end{tabular}

1) 検出せず (10 cfu/100 g 以下)
る. また, 国内産鶏肝臓の C. jejuni 污染は極めて高く, 鶏肉の污染菌数に比べ $10^{2} \sim 10^{3}$ 倍多い. それらの污染 菌数は $1.0 \times 10^{3} \sim 10^{5} \mathrm{cfu} / 100 \mathrm{~g}$ のあのが多く, $10^{6}$ $\mathrm{cfu} / 100 \mathrm{~g}$ 以上を示すむのも認められる.これはと殺後 の内臓処理において，腸管破裂などにより腸内容物が漏 出して肝臓を污染し, さらに肝臓採取後の洗浄が不十分 により，C. jejuni を十分に除去できないことによると推 察されている。

生鳥抢よび食鳥肉から分離されるC. jejuni 菌株につ いて, 本菌食中毒との関連性を調べるため, 血清型 (Penner 血清) および PFGE 型 (パルスフィールド電気 泳動パターン) などの型別が行われている，食鳥肉由来 菌株では血清型 B 群が最む多く, 次いで D 群および O 群が多く，これに対し食中毒（集団事例）由来菌株では

表 3. カンピロバクター由来別の血清群

\begin{tabular}{cccc}
\hline \multirow{2}{*}{$\begin{array}{c}\text { 血清群 } \\
\text { (Penner 血清) }\end{array}$} & \multicolumn{3}{c}{ C. jenuni 由来 } \\
\cline { 2 - 4 } & 騨肉 & 散発患者 & 集団事例 \\
\hline B & 14 & 26 & 5 \\
C & 4 & 4 & 0 \\
D & 9 & 9 & 6 \\
E & 2 & 0 & 1 \\
G & 5 & 1 & 1 \\
I & 2 & 0 & 1 \\
L & 3 & 2 & 3 \\
O & 6 & 10 & 8 \\
P & 2 & 0 & 0 \\
R & 0 & 3 & 5 \\
U & 1 & 1 & 2 \\
Y & 2 & 1 & 4 \\
Z & 2 & 0 & 0 \\
UT & 18 & 24 & 16 \\
\hline 計 & 72 & 85 & 57 \\
\hline
\end{tabular}

脱羽工程

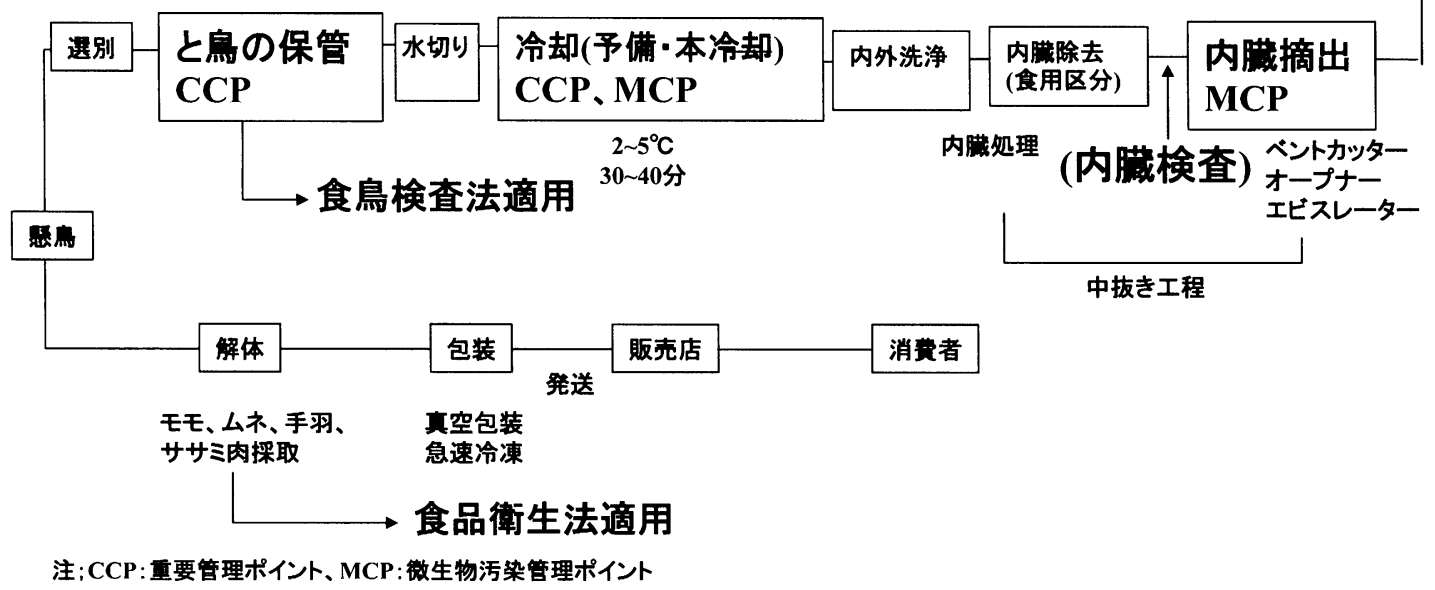

図 2. 食鳥処理（中抜き処理法）工程と重要管理点. 
$\mathrm{O}$ 群が最む多く, 次いで D, B 群が多く認められた（散発 事例由来株では B 群が最む多い)（表 3). また, PFGE 型（特に, 食鳥肉由来の血清型 B 群菌株）では食中毒由 来菌株と一致するもの, または極めて近いパターンを示 すむのか認められ, 食鳥肉と食中毒事件との関連性は極 めて高いことが示唆されている.

\section{3. 食鳥肉の C. jejuni 制御}

\section{1) 食鳥処理工程の污染}

今日, 食鳥肉の多くはブロイラー（一部, 産卵鶏で産 卵低下により廃鶏として処理されたもの）によるもので あり, 大規模食鳥処理場 (年間 30 万羽以上と殺 - 解体 処理を行う施設）では，生産農場から搬入された䳕は， 懸鳥, と殺・放血, 湯漬け, 脱羽, 中抜き, 内臓摘出, 冷却および水切りまで一貫して行われている(図 2). ま た,これら処理場では, 「食鳥処理の事業の規制および食 鳥検査に関する法律: 通称, 食鳥検査法」に基づいて衛 生管理が行われている. 本処理場での最終処理工程の水 切り後と体は, 懸鳥されて部分肉加工場 (カット工場) に移動され，ササミ，む屯肉，むね肉拈よび手羽先なよ゙ の部分肉製品とされ, 包装後出荷される.このカット工 場での解体作業は, 食品衛生法に基づいて衛生管理が行 われている.

食鳥処理場への搬入鳥（ブロイラー）のC. jejuni 污染 は, 生産農場によって大きく異なり, 生鳥での保菌が見 られない（またはほとんど見られない）農場と，高率に 保菌しであり，しかも保有菌数の極めて高い（10 $0^{6} \sim 10^{7}$ $\mathrm{cfu} / \mathrm{g}$ 糞便）農場が見られる. 生産農場ではオールイン (鶏舍に雛のすべてを一度に入れる)・オールアウト（鶏 舍の生鳥のすべてを一度に出荷する）方式が行われてい るが, その農場, 出荷時期により鶏の保菌状況は大きく 異なっている.

処理場でのと殺・解体処理工程の中で, と体への C. jejuni 污染工程としては, 脱羽, 中抜きおよび冷却工程 が指摘されている．特に，中抜き工程では自動中抜き機 の不適 (不調整) により腸管損傷・破損を起こし, 腸内 容物の污染を起こす場合がある. 本工程では污染が増加 （と体の 40 50\%以上が C. jejuni 污染）し, 菌数む $10^{3}$ $\mathrm{cfu} / 100 \mathrm{~cm}^{2}$ ) 以上を示すあのがみられる。 また，それ 以後の冷却工程後では, 35〜 40\%が污染を示し, 菌数む やや低下して污染の高い $\left(10^{3} \mathrm{cfu} / 100 \mathrm{~cm}^{2}\right.$ 以上）と体 あ減少することが認められている。（表 4).

食鳥処理場でのと殺・解体後, カット工場の部分肉加 工段階では, C. jejuni 污染率は急増 $(50 \sim 65 \%)$ を示す が, 菌数はほとんどが 1 \& $100 \mathrm{cfu} / 100 \mathrm{~cm}^{2}$ である. カット工場での解体処理工程では，処理場での腸管破損 などにより，散発的に污染の高いと体が混入することに よって, 使用器具・機材および作業者の手指なよ゙が污染 され，これらにより連続的に製品が污染され，拡散が起 こると考えられている. それゆえ, 食鳥処理場での之
表 4. 処理工場別のカンピロバクター污染

\begin{tabular}{lccccc}
\hline \multirow{2}{*}{ 検体 } & \multicolumn{5}{c}{ C. jejuni 菌数 $\left(\mathrm{cfu} / 100 \mathrm{~cm}^{2}\right)$} \\
& 当たりの検体数 (\%) & \multirow{2}{*}{ 合計 } \\
\cline { 2 - 5 } & $<24$ & $24 \sim 99$ & $100 \sim 999$ & $1,000<$ & \\
\hline 脱羽と体 & 45 & 7 & 14 & 11 & 77 \\
& $(58.4)$ & $(9.1)$ & $(18.2)$ & $(14.3)$ & \\
\hline 中抜きと体 & 38 & 5 & 19 & 15 & 77 \\
& $(49.4)$ & $(6.5)$ & $(24.7)$ & $(19.5)$ & \\
\hline 冷却後と体 & 48 & 7 & 19 & 3 & 77 \\
& $(62.3)$ & $(9.1)$ & $(24.7)$ & $(3.9)$ & \\
\hline 製品1) & 11 & 7 & 9 & 6 & 33 \\
& $(33.3)$ & $(21.2)$ & $(27.3)$ & $(18.2)$ & \\
\hline
\end{tabular}

1) 製品：屯屯肉, む效肉

殺・解体処理工程での本菌污染防止が最も重要である.

\section{2）食鳥処理における衛生管理}

微生物污染の少ない食鳥肉を生産するためには, 食鳥 生産現場での病原菌感染 (保菌) 防止之, 食鳥処理場で の病原菌（食中毒起因菌）の食鳥肉への污染防止対策が 重要である. そのためには, 食鳥処理工程での污染要因 の究明と, その衛生管理（污染防止）方法を確立するこ とが必要である.

食鳥処理場および部分肉加工場でのと殺・解体工程, および食鳥肉（むむ肉, むね肉, 手羽先など）の部分肉 処理工程を図 2 に示す. 厚生労働省食品安全部監視安全 課は, 一一般的な食鳥処理場における衛生管理総括表 (平 成 18 年 3 月, 監視安全課長通知)」を作成し, 各処理場 において自主的な衛生管理方法として HACCP プラン 作成の際のガイドラインとして活用するように通達して いる. その中で, 各と殺・解体工程ごとに危害分析を行 い, さらにその危害の防止措置, 記録文書名などを整理 している. また, 重要管理点 $(\mathrm{CCP})$ と考えられる工程に ついては, 管理基準, モニタリング法, 改善措置, 検証 方法などについても記載している. 処理工程の中で CCP 管理工程での危害要因としては，(1) 農場から処理 場への食鳥の搬入（生体受け入れ）工程（危害要因：生 鳥の抗菌・抗生物質の残留物質, 病原微生物の污染), (2) 内臟摘出後の冷却工程 (危害要因: 病原微生物の污染 之増殖, 管理基準: 冷却温度・時間, 次亜塩素ナトリウ 么の濃度), (3) 処理工程の最終製品 (丸と体) の保管 (危 害要因: 病原微生物の污染と増殖, 管理基準: 保管温度 と時間）である. また, 処理工程で微生物学的衛生管理 (MCP：微生物污染管理ポイント) として最も重要な工 程は, (1) 脱羽処理工程でのと体への糞便污染, (2) 内臓 摘出工程での腸管破損による内容物 (糞便) 污染, およ び (3) 冷却工程, 特に水冷式によると体の相互污染であ る(図 2).

\section{3）食鳥（ブロイラー）生産農場での衛生管理}

安全で衛生的な食鳥肉を生産するためには, 食鳥生産 農場から食鳥処理場, 食鳥肉加工, 流通および販売まで 
表 5. ブロイラー農家における衛生管理のポイント

\begin{tabular}{|c|c|}
\hline 健康な素雛の確保 & \multirow{7}{*}{ 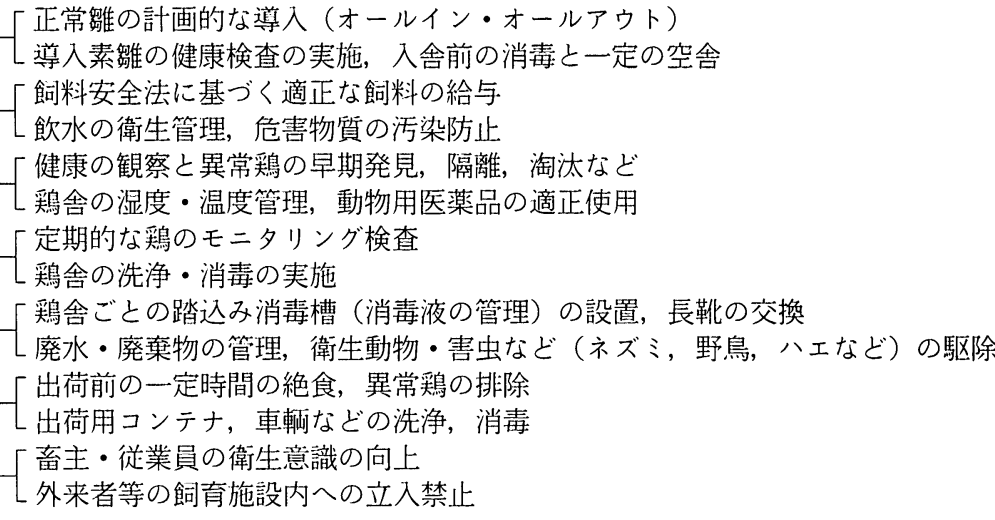 } \\
\hline 良質な飼料・飲水の確保 & \\
\hline ブロイラーの健康維持 & \\
\hline 病原菌保菌鶏の排除 & \\
\hline 鶏舎環境の整備 & \\
\hline ブロイラーの出荷 & \\
\hline 生産者等の衛生教育 & \\
\hline
\end{tabular}

一貫した衛生管理システムを構築することが重要であ る.

特に，食鳥生産場では残留抗菌・抗生物質の残留およ び食鳥への病原菌（食中毒起因菌）の感染（保菌）予防 などの対策が重要である. 生産農場における微生物污染 防止のための衛生管理ポイントを表 5 に示す. また，こ れらの衛生管理を行うための食鳥生産現場での適正農業 規範 (GAP: Good Agriculture Practice)，および食鳥飼 育のための衛生的標準作業手順：SSOP (Sanitary Standard Operation Procedure) を作成することが必要 であり，さらにこれらを文書化して保存しておくことも 大切である.これらの GAP, SSOP の実行にあたって は, 各項目ごとに点検内容やその頻度などを定め, それ らの記録デー夕を保存しておくことが重要である．生産 農場におけるC. jejuni の污染 (鳥感染) については, 本 菌が全検出されない農場が見られることから，食鳥の週 齢, 飼育環境 (鶏舎環境を含む), 飼育方法 (飼料, 給水 など）を検討することにより，制御することが可能であ ると考えられる。しかし, 本研究を行うには生産現場 （農場, 家畜保健衛生所の人たち）の協力が必須である.

\section{4. おわりに}

病原微生物污染の少ない，安全で衛生的な食鳥肉を生 産するためには，食鳥肉によるヒトの危害発生（食中毒） について，発生頻度，原因物質，発生要因などを十分に 検討して，その対策を構築することが必要である．食鳥 肉における危害要因としては, 微生物学的（食中毒起因 菌などの病原微生物), 化学的 (残留抗生・抗菌物質, 農 薬など）および物理学的（食鳥肉中の骨など異物）の 3 つの要因があるが, 最む発生頻度の高いものは微生物学 的要因 (カンピロバクター, サルモネラ, ウエルシュ菌, 黄色ブドウ球菌などの食中毒菌）によるむのである.さ らに，これらの微生物污染防止としては，食鳥（ブロイ ラ一) 生産から食鳥処理場でのと殺・解体, 加工, 流 通・販売，さらに消費に至るすべての段階まで一貫した
衛生管理システムを確立することが必要である.

そのためには「農場から食卓」までの各段階において, HACCP 方式導入の前段階としての GAP または GMP の作成, 加えて HACCP 方式の構築, さらに SOP およ び SSOPなどを確立することが必要である.

\section{文献}

1) 小野一晃, 斎藤志保子, 川森文彦, 重茂克彦, 品川邦汎: ヒト, 鷄および牛由来血清型Penner B 群, D 群, Campylobacter jejuni の PFGE 法による遺伝子解析. 日 食微誌, 22, 66-71 (2005).

2) Saito, S., Yatsuyanagi, J., Harata, S., Ito, Y., Shinagawa, K., Suzuki, N., Amano, K. and Enomoto, K.: Campylobacter jejuni isolated from retail poultry meat, bovine feces and bile, and human diarrheal samples in Japan: comparison of serotypes and genotypes. FEMS Immunol. Med. Microbiol., 45, 311-319 (2005).

3）小野一晃, 安藤陽子, 重茂克彦, 品川邦汎：MPN 法およ び直接平板塗抹法による市販鶏レバーのカンピロバク ターの定量検査. 日獣会誌, 57, 595-598 (2004).

4) Lindlom, G. B., Sjogren, E. and Kaijser, B.: Natural Campylobacter colonization in chickens raised under different environmental conditions. J. Hyg. Camb., 96, 385-391 (1986).

5）小野一晃, 斎藤志保子, 川森文彦, 後藤公吉, 重茂克彦, 品川邦汎：市販彩肉におけるカンピロバクターの定量検 查と分離菌株の血清型. 日獣会誌，57, 595-598 (2004).

6) 品川邦汎：食鳥肉の危害評価之食鳥処理場の微生物制 御, 一貫した衛生管理システムの確立が重要. 鶏の研究, 78(11), 22-28 (2003).

7) 鶏病研究会：生産現場におけるカンピロバクター污染実 態とその対策. 鶏病研報, 37, 195-216 (2001).

8) Ransom, G. M., Kaplan, B., MacNamara, A. M. and Wachsmuth, I. K.: Campylobacter prevention and control: The USDA-food safety and inspection service role and new food safety approaches. pp. 511-528 (Campylobacter, $2^{\text {nd }}$ Edition, Nachamkin, I. and Blaser, M. J. (eds.), ASM Press, Washington, D.C. (2000). 